DOE/WIPP 02-3284

Revision 0, September 2003

\title{
RH Packaging Operations Manual
}


DOE/WIPP 02-3284

Revision 0, September 2003

\section{RH Packaging Operations Manual}

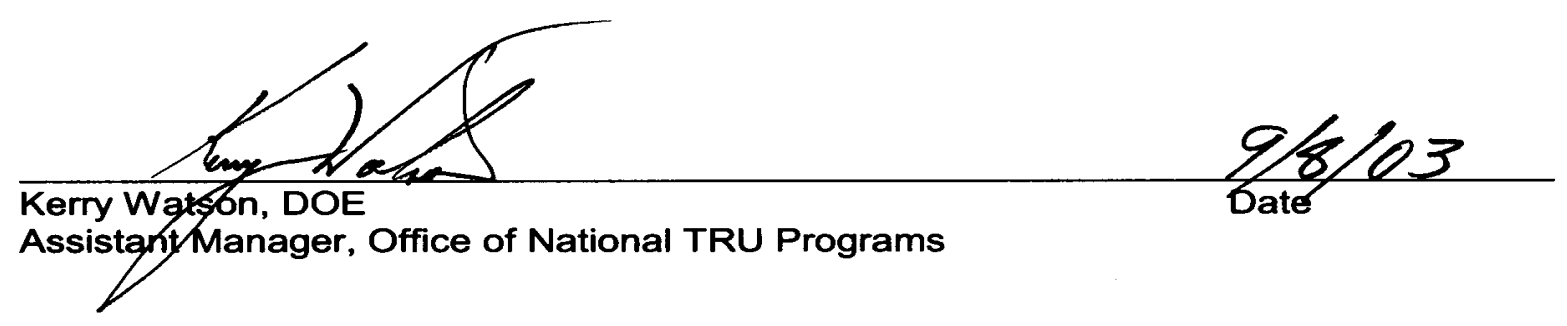

Processing and final preparation of this paper was performed by Washington TRU Solutions LLC, the management and operating (M\&O) contractor for the Waste Isolation Pilot Plant under US Department of Energy contract number DE-AC04-01AL66444. 
This document has been submitted as required to:

Office of Scientific and Technical Information

P.O. Box 62

Oak Ridge, TN 37831

(615) $576-8401$

Additional Information about this document may be obtained by calling (800) 336-9477. Copies may be obtained by contacting the National Technical Information Service, US Department of Commerce, 5285 Port Royal Road, Springfield, VA 22101. 


\section{RECORD OF REVISION}

Revision Reason for Revision/Change

$0 \quad$ New RH Packaging Operations Manual. This manual must be used with DOE/WIPP 02-3283, RH Packaging Program Guidance, and DOE/WIPP 02-3285, RH Packaging Maintenance Manual. 


\begin{tabular}{|c||}
\hline M\&O CONTRACTOR TECHNICAL REVIEW ORGANIZATIONS \\
\hline WASHINGTON TRU SOLUTIONS \\
\hline CBFO REVIEW ORGANIZATIONS \\
NATIONAL TRU PROGRAMS \\
QUALITY ASSURANCE \\
EDITORIAL \\
\hline
\end{tabular}




\section{TABLE OF CONTENTS}

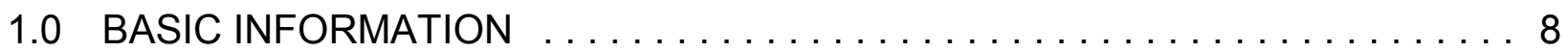

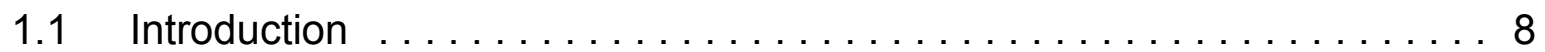

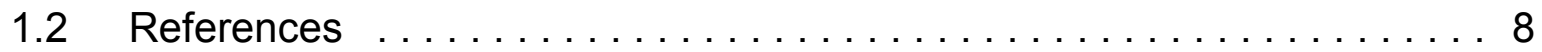

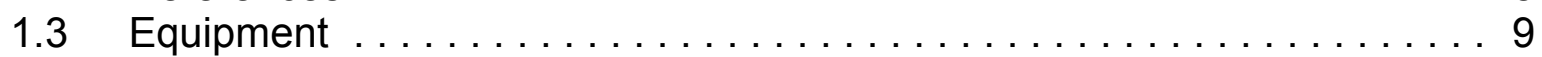

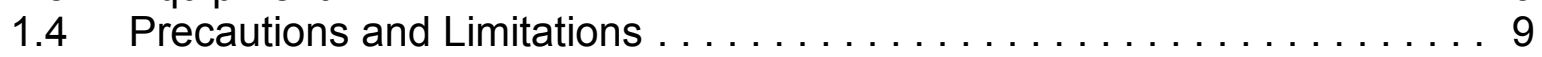

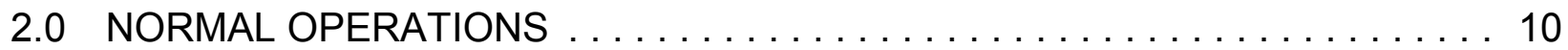

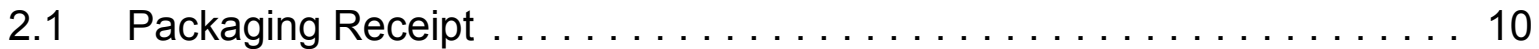

2.2 Impact Limiter Removal . . . . . . . . . . . . . . . . . . . 11

2.3 Removing Cask from Trailer . . . . . . . . . . . . . . . . . . 12

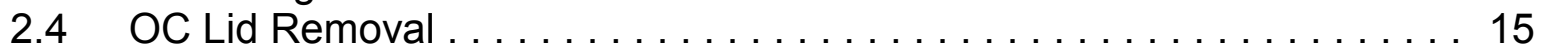

2.5 IV Lid Removal . . . . . . . . . . . . . . . . . . . . . . 15

2.6 Preloading, Shipping Operational Checks and Examinations . . . . . 16

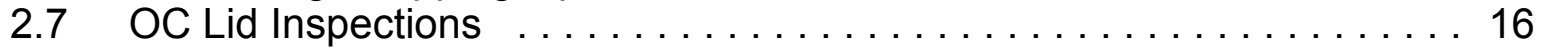

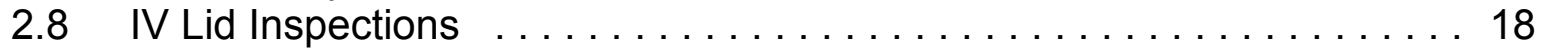

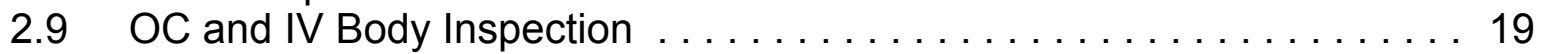

2.10 IV Cavity Inspection . . . . . . . . . . . . . . . . . . . . . . . . 19

2.11 Impact Limiter Inspection . . . . . . . . . . . . . . . . 20

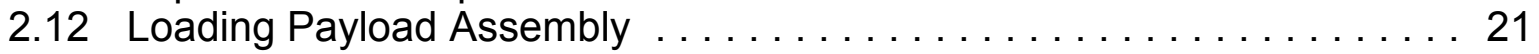

2.13 IV Lid Installation . . . . . . . . . . . . . . . . . . . . . 22

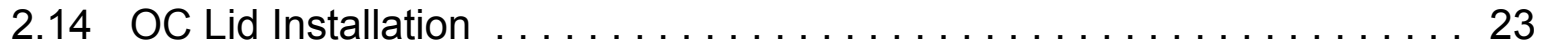

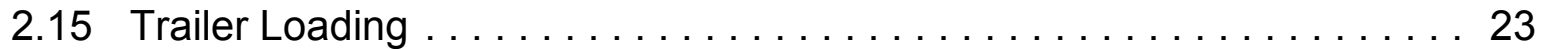

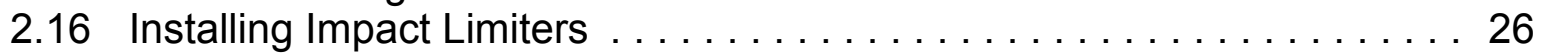

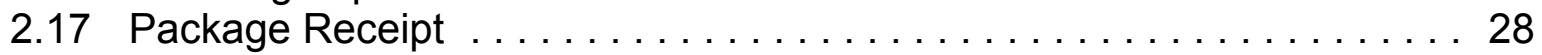

2.18 Impact Limiter Removal . . . . . . . . . . . . . . . . . . . 29

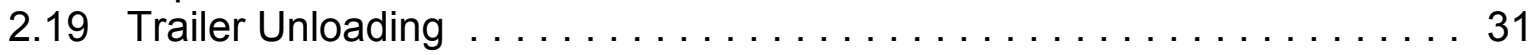

2.20 OC Lid Removal . . . . . . . . . . . . . . . . . . . . . . 33

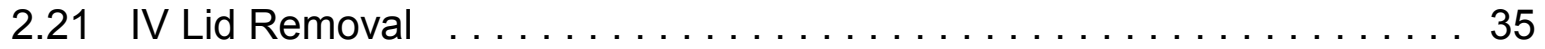

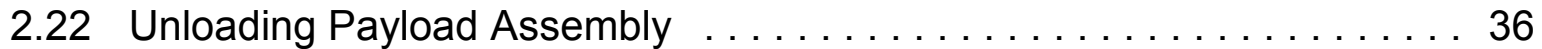

2.23 Packaging Operational Checks and Examinations . . . . . . . . . 37

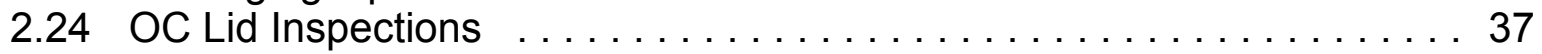

2.25 IV Lid Inspections . . . . . . . . . . . . . . . . . . 39

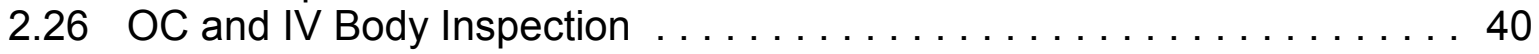

2.27 IV Cavity Inspection . . . . . . . . . . . . . . . . . . . 41

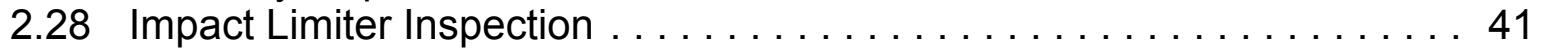

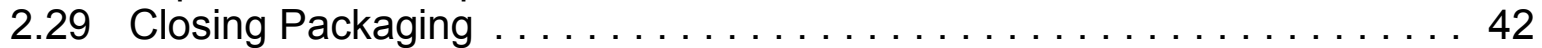

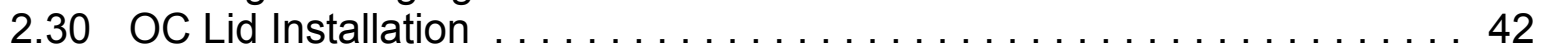

2.31 Trailer Loading . . . . . . . . . . . . . . . . . . . . . . 43

2.32 Installing Impact Limiters . . . . . . . . . . . . . . 46

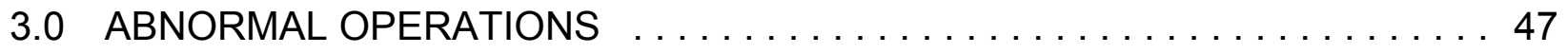

3.1 Empty IV Assembly Removal . . . . . . . . . . . . . . . . 47

3.2 Venting .......................... 48

4.0 PRE-SHIPMENT LEAKAGE RATE TESTING . . . . . . . . . . . . . . . . 49

4.1 Basic Information . . . . . . . . . . . . . . . . . . . . 49

4.2 IV Middle Main O-ring Seal . . . . . . . . . . . . . . . . . . . 51

4.3 IV Gas Sampling Port Closure Bolt O-ring Seal . . . . . . . . . . . . . . . 55

4.4 IV Backfill Port Closure Bolt O-ring Seal . . . . . . . . . . . . . . . . 57 
4.5 OC Inner Main O-ring Seal $\ldots \ldots \ldots \ldots \ldots \ldots \ldots \ldots \ldots \ldots \ldots$

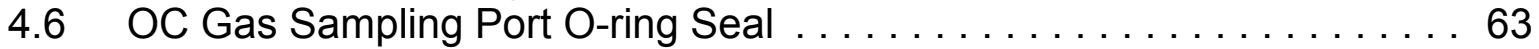

Attachment 1 - Packaging Receipt and Inspection Data Sheet $\ldots \ldots \ldots \ldots \ldots 71$

Attachment 2 - Packaging Loading Data Sheet $\ldots \ldots \ldots \ldots \ldots \ldots \ldots \ldots$

Attachment 3 - Package Trailer Data Sheet . . . . . . . . . . . . . . . . 73

Attachment 4 - Package Receipt and Processing Data Sheet . . . . . . . . . 74

Attachment 5 - Packaging Shipment Data Sheet . . . . . . . . . . . . 75

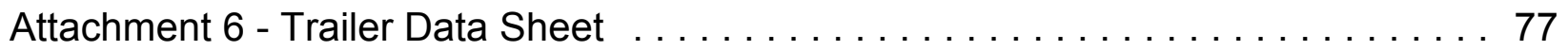

Attachment 7 - IV Pre-shipment Leakage Rate Test Data Sheet . . . . . . . . . . 78

Attachment 8 - OC Pre-shipment Leakage Rate Test Data Sheet . . . . . . . . . . 81

\section{LIST OF FIGURES}

Figure 1.1 Containment Seal $\quad \ldots \ldots \ldots \ldots \ldots \ldots \ldots \ldots \ldots \ldots \ldots \ldots \ldots \ldots \ldots \ldots$

Figure 1.2 IV Gas Sampling Port Seal $\ldots \ldots \ldots \ldots \ldots \ldots \ldots \ldots \ldots \ldots \ldots$

Figure 1.3 IV Backfill Port Seal $\ldots \ldots \ldots \ldots \ldots \ldots \ldots \ldots \ldots \ldots \ldots \ldots \ldots \ldots \ldots$

Figure 1.4 OC Containment Seal $\ldots \ldots \ldots \ldots \ldots \ldots \ldots \ldots \ldots \ldots \ldots \ldots \ldots \ldots \ldots . \ldots \ldots$

Figure 1.5 OC Gas Sampling Port Seal $\ldots \ldots \ldots \ldots \ldots \ldots \ldots \ldots \ldots \ldots$ 


\subsection{BASIC INFORMATION}

1.1 Introduction

This procedure provides operating instructions for the RH-TRU 72-B Road Cask, Waste Shipping Package.

In this document, "Packaging" refers to the assembly of components necessary to ensure compliance with the packaging requirements (not loaded with a payload).

"Package" refers to a Type B packaging that, with its radioactive contents, is designed to retain the integrity of its containment and shielding when subject to the normal conditions of transport and hypothetical accident test conditions set forth in 10 CFR Part 71.

Loading of the $\mathrm{RH} 72-\mathrm{B}$ cask can be done two ways, on the $\mathrm{RH}$ cask trailer in the vertical position or by removing the cask from the trailer and loading it in a facility designed for remote-handling $(\mathrm{RH})$. Before loading the 72-B cask, loading procedures and changes to the loading procedures for the 72-B cask must be sent to CBFO at sitedocuments@wipp.ws for approval.

\subsection{References}

\section{BASELINE DOCUMENTS}

- US Department of Energy, Safety Analysis Report for the RH-TRU 72-B Waste Shipping Package, Certificate of Compliance (C of C) 9212

- US Department of Energy, Safety Analysis Report for the RH-TRU 72-B Waste Shipping Package

- 10 CFR 835, Occupational Radiation Protection; Final Rule, Nov. 4, 1998

- 10 CFR 71, Packaging and Transportation of Radioactive Material

- DOE Order 5400.5, Radiation Protection of the Public and Environment

\section{REFERENCED DOCUMENTS}

- 49 CFR Part 172, "Hazardous Materials Table, Special Provisions, Hazardous Materials Communications, Emergency Response Information, and Training Requirements"

- 49 CFR Part 173, "Shippers - General Requirements for Shipments and Packaging"

- $R H-T R U$ 72-B Authorized Methods for Payload Control (RH TRAMPAC) 


\begin{tabular}{|lll}
\hline DOE/WIPP 02-3284 & Rev. 0 & Page 9 of 82 \\
\hline
\end{tabular}

- DOE STD 1090-2001, Hoisting and Rigging (Formerly Hoisting and Rigging Manual)

- DOE/WIPP 02-3283, RH Packaging Program Guidance

- DOE/WIPP 02-3285, RH Packaging Maintenance Manual

\subsection{Equipment}

- Measuring and Test Equipment

- $\quad$ Pressure/vacuum gage, $30 \mathrm{in}$. $\mathrm{Hg}$ to $30 \mathrm{psig}$

- Torque wrench with 15 to 20 pound foot $(\mathrm{lb}-\mathrm{ft})$ range

- $\quad$ Torque wrench with 100 to $200 \mathrm{lb}-\mathrm{ft}$ range

- $\quad$ Torque wrench with 180 to $220 \mathrm{lb}-\mathrm{ft}$ range

- $\quad$ Torque wrench with 600 to $700 \mathrm{lb}-\mathrm{ft}$ range

- $\quad$ Crane load cell with 0 to $5,000 \mathrm{lb}$-ft range (minimum)

- Other Equipment

- Inner vessel (IV) and outer cask (OC) test port tool

- $\quad$ OC lid tool

- IV lid tool

- $\quad$ Facility grapple

- $\quad$ Cask lifting yoke

- $\quad$ Rigging for impact limiter lift (two shackles and two slings, each rated to lift a minimum of $2,500 \mathrm{lbs}$ ).

- Consumable Materials

- Denatured alcohol

- Rags

- Vacuum grease

- Nickel bearing lubricant

\subsection{Precautions and Limitations}

- Maximum individual cask weight is $45,000 \mathrm{lbs}$.

\section{NOTE}

The canister capacity is $8,000 \mathrm{lbs}$ according to the SAR. The current rated capacity for the approved canisters is $5,980 \mathrm{lbs}$.

- Maximum allowable weight of loaded canister is $8,000 \mathrm{lbs}$. 
- If inner vessel is to be lifted, either empty or loaded, it shall be lifted using eye bolts in the holes on lid.

- Maximum allowable gross shipping weight for loaded packaging, including tractor and trailer, is $80,000 \mathrm{lbs}$.

\subsection{NORMAL OPERATIONS}

\section{NOTE}

Transport trailer operations, equipment checkout and shutdown, and component inspection activities must be performed. They may be performed in any order IF radiological control steps are not bypassed.

\subsection{Packaging Receipt}

\section{NOTE}

The packaging loading and unloading operation shall only be performed in a dry environment. If precipitation occurs during outdoor loading operations, $\mathrm{OC}$ and IV cavities shall be covered to prevent precipitation from entering package interior cavities. If precipitation does enter interior cavities, all freestanding water shall be removed before shipment and liquid handled according to site-specific waste management procedures.

2.1.1 Record OC serial number on Attachment 1, Packaging Receipt and Inspection Data Sheet.

\section{SIGN-OFF}

2.1.2 Verify site representative performed the following:

- Validated shipping documents

- Inspected packaging for damage

- Verified packaging is proper for contents

- Released packaging for loading

\section{SIGN-OFF}

2.1.3 Verify maintenance labels found next to name plate are current for packaging maintenance.

\section{SIGN-OFF}

2.1.4 Position transport trailer in designated parking area.

2.1.5 Install wheel chocks.

2.1.6 Lower trailer jacks (landing gear). 
2.1.7 Adjust all trailer jacks until trailer is level.

2.1.8 Install trailer stands on freestanding trailers.

2.1.9 Install aluminum deck plates on trailer (optional).

2.1.10 If needed, clean packaging using the following:

- Damp wiping cloths

- Brush and water

2.1.11 If needed, dry packaging using dry rags.

2.1.12 If "Leak Test Required" tag is present, remove tag and forward to supervisor so leak test report will be sent to WIPP M\&O contractor $\mathrm{RH}$ Packaging Maintenance Engineer.

\subsection{Impact Limiter Removal}

2.2.1 Remove bolt, nut, and flat washer from each lifting lug on impact limiters.

2.2.2 Attach rigging (two shackles and two slings, each rated to lift a minimum of 2,500 lbs) to FRONT impact limiter (front impact limiter is the one closest to the front of the trailer).

2.2.3 If equipped, remove debris ring on FRONT impact limiter.

\section{NOTE}

Bolts may be left in the impact limiter access ports after being detached from the road cask.

2.2.4 Remove six attachment bolts from FRONT impact limiter.

\section{CAUTION}

Exceeding a pull limit of $4,000 \mathrm{lbs}$ may damage $\mathrm{RH}-\mathrm{TRU}$ 72-B road cask impact limiter lifting lugs. Average weight of impact limiter is $2,560 \mathrm{lbs}$.

\section{NOTE}

A spotter must be used when removing impact limiter.

2.2.5 Remove FRONT impact limiter.

2.2.6 Place FRONT impact limiter on storage cradle on trailer, OR on impact limiter stands. 
2.2.7 Remove rigging from FRONT impact limiter.

2.2.8 Attach rigging (two shackles and two slings, each rated to lift a minimum of 2,500 lbs) to REAR impact limiter.

2.2.9 If equipped, remove debris ring on REAR impact limiter.

2.2.10 Remove six attachment bolts from REAR impact limiter.

\section{NOTE}

A spotter must be used when removing impact limiter.

2.2.11 Remove REAR impact limiter.

2.2.12 Place REAR impact limiter on storage cradle on trailer, OR on impact limiter stands.

2.2.13 Remove rigging from REAR impact limiter.

2.2.14 If impact limiters are placed on trailer then attach ratchet binders to hold them to the trailer.

\subsection{Removing Cask from Trailer}

2.3.1 Verify the following:

- Trailer stands installed on freestanding trailer.

- Trailer jack stands (landing gear) down.

- Trailer is level.

2.3.2 If using self-rotating trailer, GO TO Step 2.3.10.

\section{WARNING}

Crane must be centered on cask before attempting to lift cask off trailer.

2.3.3 Perform the following:

- Remove caps from cask center support trunnions.

- Engage rear trunnions with cask lifting yoke. 


\begin{tabular}{|lll|}
\hline DOE/WIPP 02-3284 & Rev. 0 & Page 13 of 82 \\
\hline
\end{tabular}

\section{WARNING}

Personnel must stay clear of trailer while packaging is rotating.

\section{NOTE}

A spotter must be used when rotating package.

2.3.4 Rotate packaging on forward support trunnions until it is vertical.

2.3.5 Remove forward trunnion caps.

2.3.6 Raise packaging off trailer.

2.3.7 Position packaging in vertical holding fixture supported by center trunnion.

2.3.8 Disengage cask lifting yoke from packaging.

2.3.9 GO TO Subsection 2.4, OC Lid Removal.

2.3.10 If using self-rotating trailer, verify the following:

- Hydraulic power unit de-energized.

- Hydraulic power unit hoses connected to trailer.

- Hydraulic power unit connected to site power.

- Hydraulic power unit reservoir in operating range.

- Cask rotation switch in OFF position.

- Pivot caps in holder brackets.

- Tie-down caps flipped out of the way.

- Grapple hooks engaged.

- Grapple hook pins installed

2.3.11 Remove rear trunnion tie-down caps.

2.3.12 Rotate tie-down caps back on hinges.

2.3.13 Remove center support trunnion pivot caps.

2.3.14 Place pivot caps on pivot cap brackets.

2.3.15 Energize hydraulic power unit.

2.3.16 Place hydraulic pump switch in $\mathrm{ON}$ position. 


\subsubsection{Verify the following:}

- NO visible leaks from hoses, couplings or fittings

- Hydraulic pump pressure in operating range

- Hydraulic fluid temperature in operating range

\section{WARNING}

Personnel must stay clear of trailer while packaging is rotating.

\section{NOTE}

A spotter must be used when rotating package.

2.3.18 Place cask rotation switch in RAISE position.

2.3.19 When packaging is in fully vertical position, place cask rotation switch in OFF position.

\section{WARNING}

Crane must be centered on cask before attempting to lift cask off trailer

2.3.20 Engage top trunnions with cask lifting yoke.

\begin{tabular}{|c|c|}
\hline CAUTION \\
Hydraulic system must be deactivated before releasing grapple caps. \\
\hline
\end{tabular}

2.3.21 Place hydraulic pump switch in OFF position.

2.3.22 Remove grapple hook pins.

2.3.23 Rotate grapple hook caps out of the way.

\section{NOTE}

A spotter must be used when removing packaging from trailer.

2.3.24 Remove packaging from trailer.

2.3.25 Position packaging in vertical holding fixture supported by center trunnions.

2.3.26 Disengage cask lifting yoke from packaging. 


\subsection{OC Lid Removal}

2.4.1 Install a test port tool and vent adapter on the gas sampling port turning collar as needed to seat tool in test port.

2.4.2 Open the test port tool installed in the gas sampling port by turning the handle until bolt is completely retracted into tool.

2.4.3 Remove test port tool and vent adapter from gas sampling port closure bolt.

2.4.4 Remove 18 closure bolts from OC lid.

2.4.5 Connect lift fixture and load cell to OC lid.

\section{CAUTION}

Do NOT exceed 3,670 lbs while lifting OC lid by lift points. This can be an indication of lid binding. Average weight of OC lid is 1,580 lbs.

2.4.6 If OC lid does NOT release, STOP, and contact M\&O contractor $\mathrm{RH}$ Packaging Maintenance Engineer.

2.4.7 Remove OC lid.

2.4.8 Store OC lid on lid stand, OR in a protected area to prevent damage to lid sealing surface.

\subsection{Lid Removal}

2.5.1 Install a test port tool and vent adapter on the IV gas sampling port turning collar as needed to seat tool in test port.

2.5.2 Open the test port tool installed in the gas sampling port by turning the handle until bolt is completely retracted into tool.

2.5.3 Remove test port tool from IV lid gas sampling port.

2.5.4 Unscrew eight closure bolts from IV lid until bolts are retracted into springs.

2.5.5 Install IV lid alignment tool for loading payload remotely (optional).

2.5.6 Connect lift fixture to IV lid. 


\section{CAUTION}

An indication of $2,390 \mathrm{lbs}$ or greater while lifting IV lid by lift points can be an indication of IV lid binding. Average weight of IV lid is 1,330 lbs.

2.5.7 If IV lid does NOT release, STOP, and contact WIPP M\&O contractor RH Packaging Maintenance Engineer.

2.5.8 Remove IV lid.

2.5.9 Store IV lid on lid stand,

OR in a protected area to prevent damage to lid sealing surface.

2.6 Preloading, Shipping Operational Checks and Examinations

2.6.1 Radiological Control Technicians (RCT), IF surveys for items in Subsections 2.7, OC Lid Inspections, 2.8, IV Lid Inspections, 2.9, OC and IV Body Inspection, and 2.11, Impact Limiter Inspection, were done earlier AND results were below contamination limits, THEN record applicable data for each step on Attachment 1.

2.6.2 RCT, IF surveys were NOT done in earlier steps, THEN GO TO Subsection 2.7, 2.8, 2.9, and 2.11, as applicable.

\section{NOTE}

Subsections 2.7 through 2.11 (and their steps) MUST be completed. They may be performed in any order IF radiological control steps are not bypassed.

\section{NOTE}

Damage found during inspections will be handled through the appropriate work instructions or written as a Nonconformance Report (NCR) and forwarded to WIPP M\&O contractor RH Packaging Maintenance Engineer.

\subsection{OC Lid Inspections}

2.7.1 RCT, IF survey was NOT done in an earlier step, THEN survey interior and exterior of OC lid, and record survey number and date on Attachment 1.

\section{SIGN-OFF}

2.7.2 Inspect OC lid for the following:

- Visible deformation

- Abnormal flat spots or dents $>1 / 2$ in. 
- Abnormal scratches or gouges

- Distortions on or around lifting tabs

2.7.3 If not removed earlier, remove the following:

- Seal test port closure bolt

- Gas sampling port closure bolt

2.7.4 Clean and inspect the following components for deformation, scratches and/or burrs:

- Closure bolt threads

- Seal test port insert threads

- Gas sampling port insert threads

- OC lid end forging

- Seal test port closure bolt and O-ring

- Gas sampling port closure bolt and O-ring

2.7.5 IF port closure bolts are damaged, THEN GO TO WI-RH.01, replace port closure bolts and RETURN TO Step 2.7.6.

2.7.6 IF port closure bolt O-rings are damaged, THEN GO TO WI-RH.01, replace O-rings, and RETURN TO Step 2.7.8.

2.7.7 If O-ring is acceptable after cleaning, apply high vacuum grease sparingly, and install O-ring.

2.7.8 Remove, clean, and inspect OC lid seal O-rings for the following:

- Cleanliness (no visible dirt or debris)

- Damage (voids, cracks, and gouges)

2.7.9 Clean and inspect OC lid O-ring groove sealing surfaces.

2.7.10 IF O-ring groove sealing surfaces are damaged, THEN GO TO WI-RH.07, repair, and RETURN TO Step 2.7.11.

2.7.11 IF O-ring is damaged, THEN GO TO WI-RH.02, replace O-rings, and RETURN TO Step 2.7.13.

2.7.12 If O-ring is acceptable after cleaning, apply high vacuum grease sparingly, and install O-ring.

2.7.13 Initial Attachment 1 to document OC lid components and hardware are satisfactory. 


\subsection{Lid Inspections}

2.8.1 RCT, IF survey was NOT done in an earlier step, THEN survey interior and exterior of IV lid, and record survey number and date on Attachment 1.

\section{SIGN-OFF}

2.8.2 Inspect IV lid for the following:

- Visible deformation

- Abnormal flat spots or dents $>1 / 2$ in.

- Abnormal scratches or gouges

- Distortions on or around lifting attachments

2.8.3 If not removed earlier, remove the following:

- Seal test port closure bolt

- Seal backfill port closure bolt

- Gas sampling port closure bolt

2.8.4 Clean and inspect the following components for deformation, scratches and/or burrs:

- Closure bolts

- Seal test port threads

- Gas sampling port threads

- IV lid end forging

- Backfill port threads

- Seal test port closure bolt and O-ring

- Backfill port closure bolt and O-ring

- Gas sampling port closure bolt and O-ring

2.8.5 IF port closure bolt O-ring is damaged, THEN GO TO WI-RH.01, replace O-rings, and RETURN TO Step 2.8.7.

2.8.6 Apply high vacuum grease sparingly to all O-rings that were inspected.

2.8.7 IF port closure bolts are damaged, THEN GO TO WI-RH.01, replace port closure bolt, and RETURN TO Step 2.8.9.

2.8.8 Remove, clean, and inspect IV lid seal O-rings for the following:

- Cleanliness (no visible dirt or debris)

- Damage (voids, cracks, flat spots, and gouges) 
2.8.9 Clean and inspect IV lid O-ring groove sealing surfaces.

2.8.10 IF O-ring groove sealing surfaces are damaged, THEN GO TO WI-RH.06, repair, and RETURN TO Step 2.8.11.

2.8.11 IF O-rings are damaged, THEN GO TO WI-RH.02, replace O-rings, and RETURN TO Step 2.8.13.

2.8.12 If O-ring is acceptable after cleaning, apply high vacuum grease sparingly, and install O-ring.

2.8.13 Initial Attachment 1 to document IV lid components and hardware are satisfactory.

\section{SIGN-OFF}

2.9 OC and IV Body Inspection

2.9.1 RCT, IF survey was NOT done in an earlier step, THEN survey IV interior and OC exterior, and record survey number and date on Attachment 1.

\section{SIGN-OFF}

2.9.2 Inspect OC body for:

- Punctures

- Abnormal flat spots or dents $>1 / 2$ in.

- Abnormal scratches or gouges

- Distortions on or around lifting attachments

2.9.3 Clean and inspect the following items on IV and OC body:

- Alignment pins

- Closure bolt thread inserts

- Lid sealing surfaces

2.9.4 Initial Attachment 1 to document OC and IV body components and hardware are satisfactory.

\section{SIGN-OFF}

2.10 IV Cavity Inspection

2.10.1 Inspect IV cavity for water. 


\begin{tabular}{|c|}
\hline DOE/WIPP 02-3284 \\
\hline
\end{tabular}

\section{NOTE}

Disposal of absorbent material and water will be at direction of RCT.

2.10.2 IF water is found in IV, THEN perform ONE of the following:

- Remove water using wet/dry vacuum.

- Remove water using absorbent material attached to rod.

2.10.3 IF water is in IV, THEN, GO TO Subsection 3.1, Empty IV Assembly Removal, perform steps to remove any water in OC, and RETURN TO Step 2.10.4.

2.10.4 Initial Attachment 1 to document IV cavity inspection complete.

\section{SIGN-OFF}

2.11 Impact Limiter Inspection

2.11.1 RCT, IF impact limiter contamination survey was NOT done, THEN survey, and record survey number and date on Attachment 1.

\section{SIGN-OFF}

2.11.2 Remove foreign material from attachment bolts.

2.11.3 Inspect impact limiters for:

- Punctures

- Abnormal flat spots or dents $>1 / 2$ in.

- Abnormal scratches or gouges

- Distortions on or around lifting attachments

- Plastic burnout plugs in place

2.11.4 Initial Attachment 1 to document impact limiters and hardware are satisfactory.

\section{SIGN-OFF}

2.11.5 Supervisor, review/validate and sign Attachment 1.

\section{SIGN-OFF}




\subsection{Loading Payload Assembly}

\section{NOTE}

Certain payload assembly operations can be done using site-specific remote handling techniques. Site-specific procedures should be followed for all remote handling operations.

\section{NOTE}

For shipments to WIPP, each payload container number shall be verified as having been entered in the WIPP Waste Information System (WWIS) and that shipment has been approved by WIPP WWIS Data Administrator. Verification is needed to prevent loss of time in the allowable 60-day shipping period.

2.12.1 Record OC serial number on Attachment 2, Packaging Loading Data Sheet.

\section{SIGN-OFF}

2.12.2 Verify payload is assembled using requirements stated in $\mathrm{RH}$ TRAMPAC and initial Attachment 2.

\section{SIGN-OFF}

2.12.3 Install drums into payload canister using applicable cannister loading procedures.

2.12.4 Close $\mathrm{RH}$ canister using proper procedures and techniques.

2.12.5 Canister lid shall be field welded per drawing \#165-F-007 RH-TRU 72-B Cask Removable Lid Canister Assembly.

2.12.6 Record payload assembly weight on Attachment 2 .

\section{SIGN-OFF}

2.12.7 Obtain packaging weight from WIPP WWIS Packaging Reference Data Table and record on Attachment 2.

\section{SIGN-OFF}

2.12.8 Add weights recorded in Steps 2.12.6 and 2.12.7, and record total on Attachment 2.

\section{SIGN-OFF}

2.12.9 Verify total loaded package weight does not exceed 45,000 lbs. 
2.12.10 If beta-gamma and alpha surveys are required, survey using sitespecific procedures.

2.12.11 Raise and position payload assembly over IV cavity.

2.12.12 Verify payload is centered over IV BEFORE lowering load.

\section{CAUTION}

Care should be exercised to avoid hitting, scraping, or binding payload against IV body flange.

2.12.13 Lower payload into IV.

2.13 IV Lid Installation

2.13.1 Match IV lid and body serial numbers and record IV serial number on Attachment 2.

\section{SIGN-OFF}

2.13.2 Record torque wrench calibration dates on Attachment 2.

\section{SIGN-OFF}

2.13.3 Connect lift fixture to IV lid.

\section{NOTE}

Closure of the IV lid must follow the basic steps to lid closure listed in this manual, but can be done using robotics or a hotcell.

2.13.4 Install IV lid using IV lid alignment tool (alignment tool is optional).

2.13.5 Disconnect lift fixture from IV lid.

2.13.6 Remove IV lid alignment tool.

2.13.7 Torque eight IV closure bolts in star pattern to 100 to $200 \mathrm{lb}$-ft.

\section{SIGN-OFF}

2.13.8 GO TO Section 4.0, Pre-shipment Leakage Rate Testing, perform IV pre-shipment leakage rate test, and RETURN TO

Subsection 2.14, OC Lid Installation, when leak test is complete. 


\subsection{OC Lid Installation}

2.14.1 Match OC lid and body serial numbers and record OC serial number on Attachment 2.

\section{SIGN-OFF}

2.14.2 Connect lift fixture to OC lid.

2.14.3 Install OC lid.

2.14.4 Remove lift fixture from OC lid.

\section{CAUTION}

Torque should be applied in three steps of about $220 \mathrm{lb}$-ft per load step.

2.14.5 Torque $18 \mathrm{OC}$ closure bolts in star pattern to 600 to $700 \mathrm{lb}$-ft.

\section{SIGN-OFF}

2.14.6 GO TO Subsection 4.5, OC Inner Main O-ring Seal, perform OC pre-shipment leakage rate test, and RETURN TO Step 2.14.7 when leak test is complete.

\section{SIGN-OFF}

2.14.7 Supervisor, review/validate and sign Attachment 2.

\section{SIGN-OFF}

2.15 Trailer Loading

2.15.1 Record the following on Attachment 3, Package Trailer Data Sheet:

- Shipment number

- Trailer number

- Package number

\section{SIGN-OFF}

2.15.2 Verify trailer annual inspection is current.

2.15.3 Record trailer annual inspection date on Attachment 3. 
2.15.4 Verify the following:

- Trailer stands installed on freestanding trailer.

- Trailer is chocked.

- Trailer jack stands (landing gear) down.

- Trailer is level.

- Aluminum deck plates are on trailer (optional).

2.15.5 If using self-rotating trailer, GO TO Step 2.15.15.

2.15.6 Inspect each trunnion cap and bolts for:

- Damage

- Defects

- Cleanliness

2.15.7 If needed, apply nickel Never-Seize to bolt threads.

2.15.8 Engage cask lifting trunnions using cask lifting yoke.

2.15.9 Move package to trailer and lower forward support trunnions onto trailer.

2.15.10 Install front trunnion caps and torque to 180 to $220 \mathrm{lb}$-ft.

\section{SIGN-OFF}

\section{WARNING}

Personnel must stay clear of trailer while cask is rotating.

\section{NOTE}

A spotter must be used when rotating package.

2.15.11 Rotate package on forward support trunnions until it is horizontal.

2.15.12 Lower lifting yoke to disconnect it from package.

2.15.13 Install center trunnion caps and torque to 180 to $220 \mathrm{lb}-\mathrm{ft}$.

\section{SIGN-OFF}

2.15.14 GO TO Subsection 2.16, Installing Impact Limiters. 
2.15.15 If using self-rotating trailer, verify the following:

- Hydraulic power unit de-energized.

- Hydraulic power unit hoses connected to trailer.

- Hydraulic power unit connected to site power.

- Hydraulic power unit reservoir in operating range.

- Cask rotation switch in OFF position.

- Pivot caps in holder brackets.

- Tie-down caps flipped out of the way.

- Grapple hook pins removed.

- Grapple hook caps rotated clear of trunnions.

2.15.16 Engage upper cask lifting trunnions using lifting yoke.

2.15.17 Move package to trailer.

2.15.18 Lower center support trunnions onto pivot supports.

2.15.19 When rotating trunnions are fully seated in grapple hooks, rotate grapple hook caps into position.

2.15.20 Install retaining pins.

\section{CAUTION}

Hydraulic system must be energized before disengaging lifting yoke from cask.

2.15.21 Energize hydraulic power unit.

2.15.22 Place hydraulic pump switch in ON position.

2.15.23 Verify the following:

- NO visible leaks from hoses, couplings or fittings.

- Hydraulic pump pressure in operating range.

- Hydraulic fluid temperature in operating range. 


\section{WARNING}

Personnel must stay clear of trailer while cask is rotating.

\section{NOTE}

A spotter must be used when rotating package.

2.15.24 Lower lifting yoke to disengage it from package.

2.15.25 Place cask rotation switch in LOWER position.

2.15.26 When package is in fully horizontal position, place cask rotation switch in OFF position.

2.15.27 Place hydraulic pump switch in OFF position.

2.15.28 De-energize hydraulic power unit.

2.15.29 Remove hydraulic power unit hoses from trailer.

2.15.30 Install rear trunnion caps and torque to 180 to $220 \mathrm{lb}-\mathrm{ft}$.

\section{SIGN-OFF}

2.15.31 Install center trunnion caps and torque to 180 to $220 \mathrm{lb}-\mathrm{ft}$.

\section{SIGN-OFF}

2.16 Installing Impact Limiters

2.16.1 Attach rigging (two shackles and two slings, each rated to lift a minimum of 2,500 lbs) to REAR impact limiter.

2.16.2 Install REAR impact limiter on cask (rear impact limiter goes on cask closest to the back of the trailer).

\section{CAUTION}

Torque should be applied in three steps of about $220 \mathrm{lb}$-ft per load step.

2.16.3 Torque six REAR impact limiter attachment bolts in star pattern to 600 to $700 \mathrm{lb}-\mathrm{ft}$. 
2.16.4 Remove rigging from REAR impact limiter.

2.16.5 Attach rigging to FRONT impact limiter.

2.16.6 Install FRONT impact limiter on front of package.

\section{CAUTION}

Torque should be applied in three steps of about $220 \mathrm{lb}$-ft per load step.

2.16.7 Torque six FRONT impact limiter attachment bolts in star pattern to 600 to $700 \mathrm{lb}-\mathrm{ft}$.

\section{SIGN-OFF}

2.16.8 Remove rigging from FRONT impact limiter.

2.16.9 Install bolt, flat washer, and nut into the lifting lugs on each impact limiter.

2.16.10 If equipped, install debris covers on forward and rear impact limiters.

2.16.11 Install tamper indicating security seal between OC body and REAR impact limiter (lid end of cask seal).

2.16.12 Record tamper indicating security serial number and seal date on Attachment 3.

\section{SIGN-OFF}

2.16.13 Remove aluminum deck plates from trailer (optional).

2.16.14 Record package weight on Attachment 3.

\section{SIGN-OFF}

2.16.15 RCT, survey outside of package using site-specific procedures.

HOLD POINT

2.16.16 RCT, verify surveys completed in Step 2.16.14 are within the limits stated in 10 CFR $\S 71.47$ ( $<200 \mathrm{mrem} / \mathrm{h}$ on surface; $10 \mathrm{mrem} / \mathrm{h}$ at 2 meters),

THEN release package for shipping. 
2.16.17 Verify package complies with 49 CFR Part 172, Subpart D, "Marking," Subpart E, "Labeling," and Subpart F, "Placarding."

\section{SIGN-OFF}

2.16.18 Complete shipping papers for specific shipment.

2.16.19 Verify shipping papers comply with 49 CFR Part 172, Subpart C, "Shipping Papers."

\section{SIGN-OFF}

2.16.20 Initial for trailer loading complete on Attachment 3.

\section{SIGN-OFF}

2.16.21 Supervisor, review/validate and sign data sheet.

\section{SIGN-OFF}

\subsection{Package Receipt}

\section{NOTE}

Package unloading operation shall only be performed in a dry environment. If precipitation occurs during outdoor unloading or loading operations, OC and IV cavities shall be covered to prevent precipitation from entering interior cavities. If precipitation does enter interior cavities, all freestanding water shall be removed before shipment and liquid handled according to site waste management procedures.

2.17.1 Record OC serial number on Attachment 4, Loaded Package Receipt and Processing Data Sheet.

\section{SIGN-OFF}

2.17.2 Survey package for external radiation/contamination using sitespecific procedures and record survey numbers on Attachment 4.

\section{SIGN-OFF}

2.17.3 Verify site representative performed the following:

- Validated shipping documents

- Inspected package(s) for damage

\section{SIGN-OFF}


2.17.4 Position transport trailer in designated parking area.

2.17.5 Install wheel chocks.

2.17.6 Lower trailer jacks (landing gear).

2.17.7 Adjust trailer jacks until trailer is level.

2.17.8 Install trailer stands on freestanding trailers.

2.17.9 Install aluminum deck plates on trailer (optional).

\section{HOLD POINT}

2.17.10 IF activity from surveys performed in Step 2.17.2 are within the limits stated in 10 CFR $\S 71.47(<200 \mathrm{mrem} / \mathrm{h}$ on surface; $10 \mathrm{mrem} / \mathrm{h}$ at 2 meters),

THEN release shipment for unloading.

\section{SIGN-OFF}

2.17.11 If needed, clean package using:

- Damp wiping cloths

- Brush and water

2.17.12 If needed, dry package using dry rags.

2.18 Impact Limiter Removal

2.18.1 Remove and dispose of security seal.

2.18.2 If tamper indicating device is broken or missing, follow site-specific policy.

2.18.3 Remove bolt, flat washer, and nut from each lifting lug on impact limiters.

2.18.4 Attach rigging to FRONT impact limiter.

2.18.5 If equipped, remove debris ring on FRONT impact limiter.

2.18.6 Remove six attachment bolts from FRONT impact limiter. 


\section{CAUTION}

Exceeding a pull limit of $4,000 \mathrm{lbs}$ may damage $\mathrm{RH}-\mathrm{TRU} 72-\mathrm{B}$ road cask impact limiter lifting lugs. Average weight of impact limiter is $2,560 \mathrm{lbs}$.

\section{NOTE}

A spotter must be used when removing impact limiters.

2.18.7 Remove FRONT impact limiter.

2.18.8 Place FRONT impact limiter on storage cradle on trailer, OR on impact limiter stands.

2.18.9 Remove rigging from FRONT impact limiter.

\section{HOLD POINT}

2.18.10 RCT, perform the following using site-specific procedures

- Survey previously unexposed areas of package for radiation/contamination.

- Monitor for gross levels of contamination.

\section{SIGN-OFF RCT}

2.18.11 Attach rigging to REAR impact limiter.

2.18.12 If equipped, remove debris ring from REAR impact limiter.

2.18.13 Remove six attachment bolts from REAR impact limiter.

\section{CAUTION}

Exceeding a pull limit of $4,000 \mathrm{lbs}$ may damage $\mathrm{RH}-\mathrm{TRU}$ 72-B road cask impact limiter lifting lugs.

2.18.14 Remove REAR impact limiter.

2.18.15 Place REAR impact limiter on storage cradle on trailer, OR on impact limiter stands.

2.18.16 Remove rigging from REAR impact limiter. 


\section{HOLD POINT}

2.18.17 RCT, perform the following using site-specific procedures:

- Survey previously unexposed areas of package for radiation/contamination.

- Monitor for gross levels of contamination.

\section{SIGN-OFF RCT}

\subsection{Trailer Unloading}

2.19.1 Verify the following:

- Trailer stands installed on freestanding trailer.

- Trailer jack stands (landing gear) down.

- Trailer is level.

- Wheel chocks installed.

2.19.2 If using self-rotating trailer, GO TO Step 2.19.10.

\section{WARNING}

Crane must be centered on cask before attempting to lift cask off trailer

\subsubsection{Perform the following:}

- Remove caps from cask center support trunnions.

- Engage rear trunnions with cask lifting yoke.

\section{WARNING}

Personnel must stay clear of trailer while package is rotating.

\section{NOTE}

A spotter must be used when rotating package.

2.19.4 Rotate package about forward support trunnions until it is vertical.

2.19.5 Remove forward trunnion caps.

2.19.6 Raise package off trailer. 
2.19.7 Position package in vertical holding fixture supported by center trunnion.

2.19.8 Disengage cask lifting yoke from package.

2.19.9 GO TO Subsection 2.20, OC Lid Removal.

2.19.10 If using self-rotating trailer, verify the following:

- Hydraulic power unit de-energized.

- Hydraulic power unit hoses connected to trailer.

- Hydraulic power unit connected to site power.

- Hydraulic power unit reservoir in operating range.

- Cask rotation switch in OFF position.

- Pivot caps in holder brackets.

- Tie-down caps flipped out of the way.

- Grapple hook pins removed.

- Grapple hook caps rotated clear of trunnions.

2.19.11 Remove rear trunnion tie-down caps.

2.19.12 Rotate tie-down caps back on hinges.

2.19.13 Remove center support trunnion pivot caps.

2.19.14 Place pivot caps on pivot cap brackets.

2.19.15 Energize hydraulic power unit.

2.19.16 Place hydraulic pump switch in ON position.

2.19.17 Verify the following:

- NO visible leaks from hoses, couplings or fittings.

- Hydraulic pump pressure in operating range.

- Hydraulic fluid temperature in operating range.

\section{WARNING}

Personnel must stay clear of trailer while cask is rotating.

\section{NOTE}

A spotter must be used when rotating package.

2.19.18 Place cask rotation switch in RAISE position. 
2.19.19 When package is in fully vertical position, place cask rotation switch in OFF position.

\section{WARNING}

Crane must be centered on cask before attempting to lift cask off trailer.

2.19.20 Engage top trunnions with cask lifting yoke.

\section{CAUTION}

Hydraulic system must be deactivated before releasing grapple caps.

2.19.21 Place hydraulic pump switch in OFF position.

2.19.22 Remove grapple hook pins.

2.19.23 Rotate grapple hook caps out of the way.

\section{NOTE}

A spotter must be used when removing packaging from trailer.

2.19.24 Remove package from trailer.

2.19.25 Position package in vertical holding fixture supported by center trunnions.

2.19.26 Disengage cask lifting yoke from package.

2.20 OC Lid Removal

2.20.1 Install a test port tool and vent adapter on the gas sampling port turning collar as needed to seat tool in test port.

2.20.2 Open the test port tool installed in the gas sampling port by turning the handle until bolt is completely retracted into tool.

2.20.3 Remove test port tool from OC lid gas sampling port. 
HOLD POINT

2.20.4 RCT, perform the following using site-specific procedures

- Take contamination smear(s) on OC gas sampling port closure bolt.

- Monitor for gross levels of contamination.

- Verify activity is below acceptable limits.

\section{SIGN-OFF RCT}

2.20.5 Remove 18 lid closure bolts from OC lid.

2.20.6 Connect OC lid lift fixture and load cell to OC lid.

\section{CAUTION}

Exceeding crane load cell indication of 3,670 lbs may damage cask OC lid lift socket.

2.20.7 IF lid does NOT release,

THEN contact M\&O contractor RH Packaging Maintenance Engineer.

2.20.8 Raise OC lid slowly about 6 in. above top of IV lid, or as directed by RCT.

\section{HOLD POINT}

2.20.9 RCT, perform the following using site-specific procedures:

- Survey OC lid interior surface and IV lid exterior surface for radiation/contamination.

- Monitor for gross levels of contamination.

- Verify activity is below acceptable limits.

\section{SIGN-OFF RCT}

2.20.10 Position OC lid on storage stand. 


\subsection{Lid Removal}

2.21.1 Install test port and vent adapter tool into IV lid gas sampling port.

2.21.2 Unscrew IV lid gas sampling port closure bolt.

2.21.3 Wait for pressure to equalize.

2.21.4 Remove test port tool and vent adapter from IV lid gas sampling port.

\section{HOLD POINT}

2.21.5 RCT, perform the following using site-specific procedures

- Survey IV gas sampling port for radiation/contamination.

- Monitor smears for gross levels of contamination.

- Verify activity is below acceptable limits.

\section{SIGN-OFF RCT}

\subsubsection{Connect IV lift fixture to IV lid.}

\section{NOTE}

Certain payload assembly operations can be done using site-specific remote handling techniques. Site-specific procedures should be followed for all remote handling operations.

2.21.7 De-tension eight closure bolts for IV lid.

2.21.8 Install IV lid alignment tool (optional).

\section{CAUTION}

Exceeding crane load cell indication of 2,390 lbs may damage cask IV lid lift socket.

2.21.9 IF lid does NOT release, THEN contact M\&O contractor RH Packaging Maintenance Engineer.

2.21.10 Raise IV lid to clear IV body. 


\section{HOLD POINT}

2.21.11 RCT, perform the following using site-specific procedures:

- Survey IV lid interior surface and top of payload for contamination.

- Monitor for gross levels of contamination.

- Verify activity is below acceptable limits.

\section{SIGN-OFF RCT}

2.21.12 Position IV lid on storage stand.

2.22 Unloading Payload Assembly

\section{NOTE}

Site-specific procedures should be followed for remote unloading and handling of $\mathrm{RH}$ payload assembly. Inspection of payload assembly will be done remotely.

\subsubsection{Engage payload using crane.}

\section{NOTE}

Perform Steps 2.22.2, 2.22.3, and 2.22.4 concurrently to remove payload.

2.22.2 Raise payload canister slowly.

2.22.3 Inspect payload for damage.

\section{SIGN-OFF}

\section{HOLD POINT}

2.22.4 RCT, perform the following using site-specific procedures:

- Survey payload assembly for contamination as it is raised.

- Monitor for gross levels of contamination.

- Verify activity is below acceptable limits.

\section{SIGN-OFF RCT}

2.22.5 If payload is damaged, follow site-specific procedures.

2.22.6 Place payload canister in designated area. 
Rev. 0

2.22.7 Supervisor, review/validate and sign Attachment 4 .

SIGN-OFF

2.23 Packaging Operational Checks and Examinations

2.23.1 Record OC serial number on Attachment 5, Empty Packaging Shipment Data Sheet.

\section{SIGN-OFF}

2.23.2 Record torque wrench calibration dates on Attachment 2.

\section{SIGN-OFF}

2.23.3 Verify packaging maintenance is current by checking maintenance labels adjacent to name plate.

\section{SIGN-OFF}

2.23.4 RCT, IF surveys for items in Steps 2.24.1, 2.25.1, 2.26.1, and 2.28.1 were done AND results were below contamination limits, THEN record applicable data for each step on Attachment 5.

2.23.5 RCT, IF surveys were NOT done on an earlier step, THEN GO TO Steps 2.24.1, 2.25.1, 2.26.1, and 2.28.1, as applicable.

\section{NOTE}

Subsections 2.27, IV Cavity Inspection, through Subsection 2.31, Trailer Loading (and their steps), MUST be completed. They may be performed in any order IF radiological control steps are not bypassed.

\section{NOTE}

Damage found during inspections will be handled through the appropriate work instructions. Damage that cannot be handled through work instructions must be written as an NCR and forwarded to WIPP M\&O contractor RH Packaging Maintenance Engineer.

\subsection{OC Lid Inspections}

2.24.1 RCT, IF survey was NOT done on an earlier step, THEN survey interior and exterior of OC lid, and record applicable data on Attachment 5.

\section{SIGN-OFF}


2.24.2 Inspect OC lid for the following:

- Visible deformation

- Abnormal flat spots or dents $>1 / 2$ in.

- Abnormal scratches or gouges

- Distortions on or around lifting tabs

2.24.3 If not removed earlier, remove the following using test port tool and vent adapter:

- Seal test port closure bolt

- Gas sampling port closure bolt

2.24.4 Clean and inspect the following components for deformation, scratches and/or burrs:

- Closure bolt threads

- Seal test port insert threads

- Gas sampling port insert threads

- OC lid end forging

- Seal test port closure bolt and O-ring

- Gas sampling port closure bolt and O-ring

2.24.5 IF port closure bolts are damaged, THEN GO TO WI-RH.01, replace port closure bolts, and RETURN TO Step 2.24.6.

2.24.6 IF port closure bolt O-rings are damaged, THEN GO TO WI-RH.01, replace O-rings, and RETURN TO Step 2.24.8.

2.24.7 If O-ring is acceptable after cleaning, apply high vacuum grease sparingly, and install O-ring.

2.24.8 Remove, clean, and inspect OC lid seal O-rings for the following:

- Cleanliness (no visible dirt or debris)

- Damage (voids, cracks, and gouges)

2.24.9 Clean and inspect OC lid O-ring groove sealing surfaces.

2.24.10 IF O-ring groove sealing surfaces are damaged, THEN GO TO WI-RH.07, repair, and RETURN TO Step 2.24.11.

2.24.11 IF lid O-ring is damaged, THEN GO TO WI-RH.02, replace O-rings, and RETURN TO Step 2.24.13. 
2.24.12 If O-ring is acceptable after cleaning, apply high vacuum grease sparingly, and install O-ring.

2.24.13 Initial Attachment 5 to document OC lid components and hardware are satisfactory.

\section{SIGN-OFF}

2.25 IV Lid Inspections

2.25.1 RCT, IF survey was NOT done on an earlier step, THEN survey interior and exterior of IV lid and record applicable data on Attachment 5.

\section{SIGN-OFF}

2.25.2 Inspect IV lid for the following:

- Visible deformation

- Abnormal flat spots or dents $>1 / 2$ in.

- Abnormal scratches or gouges

- Distortions on or around lifting attachments

2.25.3 If not removed earlier, remove the following using test port tool and vent adapter:

- Seal test port closure bolt

- Seal backfill port closure bolt

- Gas sampling port closure bolt

2.25.4 Clean and inspect the following components for deformation, scratches and/or burrs:

- Closure bolts

- Seal test port insert threads

- Gas sampling port insert threads

- IV lid end forging

- Backfill port insert threads

- Seal test port closure bolt and O-ring

- Backfill port closure bolt and O-ring

- Gas sampling port closure bolt and O-ring

2.25.5 IF port closure bolt O-ring is damaged, THEN GO TO WI-RH.01, replace O-rings, and RETURN TO Step 2.25.7.

2.25.6 Apply high vacuum grease sparingly to all O-rings that were inspected. 
2.25.7 IF port closure bolts are damaged, THEN GO TO WI-RH.01, replace port closure bolt, and RETURN TO Step 2.25.8.

2.25.8 Remove, clean, and inspect IV lid seal O-rings for the following:

- Cleanliness (no visible dirt or debris)

- Damage (voids, cracks, and gouges)

2.25.9 Clean and inspect IV lid O-ring groove sealing surfaces.

2.25.10 IF O-ring groove sealing surfaces are damaged, THEN GO TO WI-RH.06, repair, and RETURN TO Step 2.25.11.

2.25.11 IF lid O-rings are damaged, THEN GO TO WI-RH.02, replace O-rings, and RETURN TO Step 2.25.13.

2.25.12 If lid O-ring is acceptable after cleaning, apply high vacuum grease sparingly, and install O-ring.

2.25.13 Initial Attachment 5 to document IV lid components and hardware are satisfactory.

\section{SIGN-OFF}

2.26 OC and IV Body Inspection

2.26.1 RCT, IF survey was NOT done on an earlier step, THEN survey IV interior and OC exterior, and record data on Attachment 5.

\section{SIGN-OFF}

2.26.2 Inspect OC body for:

- Punctures

- Abnormal flat spots or dents $>1 / 2$ in.

- Abnormal scratches or gouges

- Distortions on or around lifting attachments

2.26.3 Clean and inspect the following items on IV and OC body:

- Alignment pins

- Closure bolt thread inserts

- Lid sealing surfaces

2.26.4 Initial Attachment 5 to document OC and IV body components and hardware are satisfactory. 


\begin{tabular}{|lll} 
DOE/WIPP 02-3284 & Rev. 0 & Page 41 of 82 \\
\hline
\end{tabular}

\subsection{Cavity Inspection}

2.27.1 Inspect IV cavity for water.

\section{NOTE}

Disposal of absorbent material and water will be at direction of RCT.

2.27.2 IF water is in IV, THEN perform ONE of the following:

- Remove water using wet/dry vacuum.

- Remove water using absorbent material attached to rod.

2.27.3 IF water is in IV, THEN, GO TO Subsection 3.1, perform steps to remove any water in OC, and RETURN TO Step 2.27.4.

2.27.4 Initial Attachment 5 to document IV cavity inspection.

\section{SIGN-OFF}

2.28 Impact Limiter Inspection

2.28.1 RCT, IF impact limiter contamination survey was NOT done on an earlier step, THEN survey and record data on Attachment 5.

\section{SIGN-OFF}

2.28.2 Remove foreign material from attachment bolts.

2.28.3 Inspect impact limiters for:

- Punctures

- Abnormal flat spots or dents $>1 / 2$ in.

- Abnormal scratches or gouges

- Distortions on or around lifting attachments

- Plastic burnout plugs in place

2.28.4 Initial Attachment 5 to document impact limiters and hardware are satisfactory.

\section{SIGN-OFF}

2.28.5 Verify all pre-shipment inspections are complete.

\section{SIGN-OFF}




\subsection{Closing Packaging}

2.29.1 Match IV lid and OC body serial numbers.

2.29.2 Record IV serial number on Attachment 5.

\section{SIGN-OFF}

2.29.3 Connect lift fixture to IV lid.

2.29.4 Install IV lid.

2.29.5 Disconnect lift fixture from IV lid.

2.29.6 Torque eight IV lid closure bolts in star pattern to 100 to $200 \mathrm{lb}$-ft.

\section{SIGN-OFF}

2.29.7 Install IV seal test port closure bolt.

2.29.8 Torque IV seal test port closure bolt to 15 to $20 \mathrm{lb}-\mathrm{ft}$.

\section{SIGN-OFF}

2.29.9 Install IV backfill port closure bolt.

2.29.10 Torque IV backfill port closure bolt to 15 to $20 \mathrm{lb}$-ft.

\section{SIGN-OFF}

2.29.11 Install IV gas sampling port closure bolt.

2.29.12 Torque IV gas sampling port closure bolt to 15 to $20 \mathrm{lb}$-ft.

\section{SIGN-OFF}

2.30 OC Lid Installation

2.30.1 Match OC lid and OC body serial numbers.

2.30.2 Record OC serial number on Attachment 5.

\section{SIGN-OFF}

2.30.3 Connect lift fixture to OC lid.

2.30.4 Install OC lid.

2.30.5 Remove lift fixture from OC lid. 


\section{CAUTION}

Torque should be applied in three steps of about $220 \mathrm{lb}$-ft per load step.

2.30.6 Torque $18 \mathrm{OC}$ lid closure bolts in star pattern to 600 to $700 \mathrm{lb}$-ft.

\section{SIGN-OFF}

2.30.7 Install OC seal test port closure bolt.

2.30.8 Torque OC seal test port closure bolt to $15 \mathrm{to} 20 \mathrm{lb}$-ft.

\section{SIGN-OFF}

2.30.9 Install OC gas sampling port closure bolt.

2.30.10 Torque OC gas sampling port closure bolt to 15 to $20 \mathrm{lb}-\mathrm{ft}$.

\section{SIGN-OFF}

2.30.11 Verify unit is ready for transport.

\section{SIGN-OFF}

2.30.12 Supervisor, review/validate and sign Attachment 5 .

\section{SIGN-OFF}

\subsection{Trailer Loading}

2.31.1 Record the following on Attachment 6, Trailer Data Sheet:
- Shipment number
- Trailer number
- Package number

\section{SIGN-OFF}

2.31.2 Verify trailer annual inspection is current.

2.31.3 Record trailer annual inspection date on Attachment 6.

\section{SIGN-OFF}

2.31.4 Verify the following:

- Trailer wheels chocked.

- Trailer stands installed on freestanding trailers. 
- Trailer jack stands (landing gear) down.

- Trailer is level.

2.31.5 If using self-rotating trailer, GO TO Step 2.31.16.

2.31.6 Inspect each trunnion cap and bolt for:

$\begin{array}{ll}\text { - } & \text { Damage } \\ \text { - } & \text { Defects } \\ \text { Cleanliness }\end{array}$

2.31.7 If needed, apply nickel Never-Seize to bolts.

2.31.8 Engage cask lifting trunnions using cask lifting yoke.

2.31.9 Move package to trailer.

2.31.10 Lower forward support trunnions onto trailer.

2.31.11 Install front trunnion caps and torque to 180 to $220 \mathrm{lb}-\mathrm{ft}$.

\section{SIGN-OFF}

\section{WARNING}

Personnel must stay clear of trailer while cask is rotating.

\section{NOTE}

A spotter must be used when rotating package.

2.31.12 Rotate package on forward support trunnions until it is horizontal.

2.31.13 Lower lifting yoke to disconnect it from package.

2.31.14 Install center trunnion caps and torque to 180 to $220 \mathrm{lb}$-ft.

\section{SIGN-OFF}

2.31.15 GO TO Subsection 2.32, Installing Impact Limiters.

2.31.16 If using self-rotating trailer, verify the following:

- Hydraulic power unit de-energized.

- Hydraulic power unit hoses connected to trailer.

- Hydraulic power unit connected to site power.

- Hydraulic power unit reservoir in operating range.

- Cask rotation switch in OFF position. 
- Pivot caps in holder brackets.

- Tie-down caps flipped out of the way.

- Grapple hook pins removed.

- Grapple hook caps rotated clear of trunnions.

2.31.17 Engage upper cask lifting trunnions using lifting yoke.

2.31.18 Move packaging to trailer.

2.31.19 Lower center support trunnions onto pivot supports.

2.31.20 When rotating trunnions are fully seated in grapple hooks, rotate grapple hook caps into place, and install retaining pins.

\section{CAUTION}

Hydraulic system must be energized before disengaging lifting yoke from packaging.

2.31.21 Energize hydraulic power unit.

2.31.22 Place hydraulic pump switch in ON position.

2.31.23 Verify the following:

- NO visible leaks from hoses, couplings or fittings.

- Hydraulic pump pressure in operating range.

- Hydraulic fluid temperature in operating range.

\section{WARNING}

Personnel must stay clear of trailer while packaging is rotating.

\section{NOTE}

A spotter must be used when rotating package.

2.31.24 Lower lifting yoke to disengage it from packaging.

2.31.25 Place cask rotation switch in LOWER position.

2.31.26 When packaging is in fully horizontal position, place cask rotation switch in OFF position.

2.31.27 Place hydraulic pump switch in OFF position. 
2.31.28 De-energize hydraulic power unit.

2.31.29 Remove hydraulic power unit hoses from trailer.

2.31.30 Install rear trunnion caps and torque to 180 to $220 \mathrm{lb}$-ft.

\section{SIGN-OFF}

2.31.31 Install center support trunnion caps and torque to 180 to $220 \mathrm{lb}$-ft.

\section{SIGN-OFF}

2.32 Installing Impact Limiters

2.32.1 Attach rigging (two shackles and two slings, each rated to lift a minimum of 2,500 lbs) to REAR impact limiter (rear impact limiter goes on the cask closest to the rear of the trailer).

2.32.2 Install REAR impact limiter on packaging.

\section{CAUTION}

Torque should be applied in three steps of about $220 \mathrm{lb}$-ft per load step.

2.32.3 Torque six REAR impact limiter attachment bolts in star pattern to 600 to $700 \mathrm{lb}-\mathrm{ft}$.

\section{SIGN-OFF}

2.32.4 Remove rigging from REAR impact limiter.

2.32.5 Install rigging to FRONT impact limiter.

2.32.6 Install FRONT impact limiter on front of packaging.

\section{CAUTION}

Torque should be applied in three steps of about $220 \mathrm{lb}$-ft per load step.

2.32.7 Torque six FRONT impact limiter attachment bolts in star pattern to 600 to $700 \mathrm{lb}-\mathrm{ft}$.

\section{SIGN-OFF}


2.32.8 Remove rigging from FRONT impact limiter.

2.32.9 Install bolt, nut, and flat washer into each lifting lug on impact limiter.

2.32.10 If equipped, install debris cover on FRONT impact limiter.

2.32.11 If equipped, install debris cover on REAR impact limiter.

2.32.12 Record packaging weight on Attachment 6.

\section{SIGN-OFF}

2.32.13 Verify packaging complies with 49 CFR Part 172 , Subparts D, E, and $F$.

\section{SIGN-OFF}

2.32.14 Complete shipping papers for specific shipment.

2.32.15 Verify shipping papers comply with 49 CFR Part 172 , Subpart C.

\section{SIGN-OFF}

2.32.16 Initial for trailer loading complete on Attachment 6 .

\section{SIGN-OFF}

2.32.17 Supervisor, review/validate and sign data sheet.

\section{SIGN-OFF}

\subsection{ABNORMAL OPERATIONS}

\section{NOTE}

Section 3.1, is performed ONLY if water is found in IV, or during annual maintenance.

\subsection{Empty IV Assembly Removal}

3.1.1 Verify IV lid has been installed and torqued.

3.1.2 Attach eye bolts to the four holes on IV lid.

3.1.3 Attach rigging and crane to eye bolts on IV lid.

3.1.4 Remove empty IV assembly from OC body using crane and rigging. 
3.1.5 If required by site-specific policy to ensure personnel safety, RCT shall survey OC interior for radiation/contamination BEFORE initiating $\mathrm{OC}$ inspection process.

3.1.6 Inspect visually, OR swab for presence of water in bottom of OC.

3.1.7 If freestanding water is NOT seen in bottom of OC body, GO TO Step 3.1.12.

\section{WARNING}

Operator shall don protective clothing and equipment before entering OC cavity. Operator also shall enter OC cavity using precautions to prevent damage to $\mathrm{OC}$ body sealing flange. OC cavity has the potential of being a confined space. Refer to site-specific procedures for entrance.

3.1.8 IF water is found in OC,

THEN perform ONE of the following:

- Remove water using wet/dry vacuum.

- Remove using absorbent material attached to rod.

\section{NOTE}

Cleaning and waste materials should be managed according to site-specific procedures waste management procedures.

3.1.9 Remove equipment and exit OC cavity using precautions not to damage OC body sealing flange.

3.1.10 Verify OC is free of standing water.

3.1.11 Ensure IV body is aligned with ports on IV lid in the proper position relative to OC body.

3.1.12 Reinstall IV assembly into OC body using crane and rigging.

3.1.13 Remove crane, rigging, and eye bolts from IV lid.

\subsection{Venting}

3.2.1 IF venting is required, THEN perform applicable Subsections 2.20, OC Lid Removal, and 2.21, IV Lid Removal.

3.2.2 Wait three minutes. 
3.2.3 Go TO Subsection 2.13, IV Lid Installation, reinstall lids using Subsections 2.13 and 2.14 .

\subsection{PRE-SHIPMENT LEAKAGE RATE TESTING}

\subsection{Basic Information}

\subsubsection{Introduction}

This procedure provides instructions for performing IV and OC preshipment leakage rate test on the following packaging seals and corresponding seal surfaces using a nondestructive helium $(\mathrm{He})$ leak test.

- IV middle main O-ring seal

- IV gas sampling port closure bolt O-ring seal

- IV backfill port closure bolt O-ring seal

- OC inner main O-ring seal

- OC gas sampling port closure bolt O-ring seal

\subsubsection{References}

- U.S. Nuclear Regulatory Commission Information Notice 97-57: Leak Testing of Packaging Used in the Transport of Radioactive Material

- US Department of Energy, Safety Analysis Report for the RH-TRU 72-B Waste Shipping Package, Certificate of Compliance (C of C) 9212

- U.S. Department of Energy, Safety Analysis Report for the RH-TRU 72-B Waste Shipping Package

- ANSI N 14.5, 1997, Radioactive Materials-Leakage Tests of Packages for Shipment

- ASNT, Recommended Practice No. SNT-TC-1A, June 1980

- U.S. Nuclear Regulatory Commission Information Notice 97-57, Leak Testing of Packaging Used in the Transport of Radioactive Material

- DOE/WIPP 02-3283, RH Packaging Program Guidance

- DOE/WIPP 02-3285, RH Packaging Maintenance Manual 


\subsubsection{Equipment}

- $\quad$ MEASURING AND TEST EQUIPMENT

- Varian 959 Helium Mass Spectrometer Leak Detector (MSLD) with an $8.2 \mathrm{cfm}$ backing pump OR LH UL 100+ MSLD with an $0.9 \mathrm{cfm}$ backing pump

- Roughing pump

- Helium standard leak for calibrating MSLD

- Pressure/vacuum gauge, $30 \mathrm{in}$. $\mathrm{Hg}$ to $30 \mathrm{psig}$

- Temperature measuring device 0 to 100 degrees minimum (Centigrade scale)

- Ambient atmospheric pressure measuring device

- Watch or stopwatch, digital or sweep second hand (no calibration required)

- Torque wrench, 15 to $20 \mathrm{lb}$-ft. capacity

- $\quad$ SPECIAL TEST EQUIPMENT

- IV/OC test port tools

- Miscellaneous hardware and test connections

- CONSUMABLE MATERIALS

- Welding grade helium 99\% (with conformance certifications)

- Argon or nitrogen (purge gas)

\subsubsection{Precautions and Limitations}

- The following leak test procedure may be used, or each user may develop and qualify a procedure by the guidelines of ANSI N14.5, 1997. Sites that opt to qualify their own leak test procedure must submit it (with test records) to the CBFO at sitedocuments@wipp.ws. for approval.

- Leak testing of RH packaging shall be performed by personnel qualified following the American Society for Nondestructive Testing Recommended Practice No. SNT-TC-1A, June 1980 edition and supplements.

- This procedure is qualified using a Varian 959 MSLD with an $8.2 \mathrm{cfm}$ vacuum pump. The test line configuration qualified for use with this instrument is a 1 in. minimum I.D. $x 12 \mathrm{ft}$ maximum length. The L/H UL $100+$ with a $0.9 \mathrm{cfm}$ vacuum 
pump is qualified using a test line of $1 / 2$ in. minimum I.D. $\times 10 \mathrm{ft}$ maximum length.

- The He leak detector shall be calibrated to a minimum sensitivity of $1.3 \times 10^{-7}$ standard cubic centimeters per second (scc/s) He.

- The leakage rate acceptance criterion of $1 \times 10^{-7} \mathrm{scc} / \mathrm{s}$ of air equates to a leakage rate of $2.6 \times 10^{-7} \mathrm{scc} / \mathrm{s} \mathrm{He}$. The He leakage rate is valid only for a component of $\geq 4.4^{\circ} \mathrm{C}$. The acceptable $\mathrm{He}$ leakage rate increases with temperature, but as a conservative measure, the acceptance criterion of $2.6 \times 10^{-7} \mathrm{scc} / \mathrm{s}$ He will be used.

\subsubsection{Prerequisite Actions}

- Verify air flow through leak check and leak detection tools.

- Verify packaging surface is free of contaminants that might mask a leak. Interior and exterior surfaces shall be dry.

\subsection{Middle Main O-ring Seal}

4.2.1 Record the following on Attachment 7, IV Pre-shipment Leakage Rate Test Data Sheet:

- IV body serial number $(\mathrm{S} / \mathrm{N})$

- IV lid S/N

- Date of leak test

- MSLD model number

- Pressure/vacuum gauge $\mathrm{S} / \mathrm{N}$ and calibration due date

- Thermometer $\mathrm{S} / \mathrm{N}$ and calibration due date

- Torque wrench S/Ns and calibration due dates

- Standard leak $\mathrm{S} / \mathrm{N}$ and calibration due date

- Barometer S/N and calibration due date

\section{SIGN-OFF}

4.2.2 Verify IV lid is installed.

4.2.3 Verify IV seal test port closure bolt is removed.

4.2.4 Install a test port tool into seal test port turning collar as needed to seat tool in test port.

4.2.5 Verify IV backfill port closure bolt is installed.

4.2.6 Verify IV gas sampling port closure bolt is installed and torqued to 15 to $20 \mathrm{lb}-\mathrm{ft}$. 
4.2.7 Install a test port tool into backfill port turning collar as needed to seat tool in test port.

4.2.8 Measure IV surface temperature.

4.2.9 If temperature is $<4.4^{\circ} \mathrm{C}$, stop test until surface temperature is $\geq 4.4^{\circ} \mathrm{C}$.

4.2.10 Record IV surface temperature on Attachment 7.

\section{SIGN-OFF}

4.2.11 Connect a vacuum pump and helium gas source to test port tool installed in backfill port (see Figure 1.1, Containment Seal).

4.2.12 Open test port tool installed in backfill port by turning the cap counterclockwise until port bolt is retracted completely into test port tool.

4.2.13 Open isolation valve to vacuum pump.

4.2.14 Start vacuum pump.

4.2.15 Record ambient atmospheric pressure (Patm) on Attachment 7.

\section{SIGN-OFF}

4.2.16 Evacuate backfill port cavity to $\geq 90 \%$ vacuum (90\% of atmospheric pressure or better).

4.2.17 Record vacuum reading (V1) on Attachment 7.

\section{SIGN-OFF}

4.2.18 Calculate He concentration correction factor (CCF) as follows:

$$
\mathrm{CCF}=\frac{\text { Patm }}{\mathrm{V} 1}
$$

\subsubsection{Record CCF on Attachment 7.}

\section{SIGN-OFF}

4.2.20 Perform pretest calibration of MSLD (to the temperature corrected standard leak value) and record results on Attachment 7.

\section{SIGN-OFF}


4.2.21 Connect MSLD to test port tool installed in seal test port (see Figure 1.1).

4.2.22 Evacuate seal test port.

4.2.23 Close vacuum valve and stop vacuum pump.

\section{NOTE}

To measure $a \leq 2.6 \times 10^{-7} \mathrm{scc} / \mathrm{s}$ He leakage rate, indicated He background must stabilize at $\leq 2.6 \times 10^{-7} \mathrm{scc} / \mathrm{s} \mathrm{He}$ and remain below the limit for a minimum of 3 minutes.

4.2.24 Record He background (RB) on Attachment 7.

\section{SIGN-OFF}

4.2.25 Open He valve and backfill cavity with He to a pressure slightly greater than atmospheric pressure (+1 psi, $-0 \mathrm{psi})$.

4.2.26 Close He valve.

4.2.27 Record backfill pressure reading on Attachment 7 .

\section{SIGN-OFF}

4.2.28 Install backfill port closure bolt and torque to 15 to $20 \mathrm{lb}$-ft.

\section{SIGN-OFF}

\section{NOTE}

A dwell time of 3 minutes will be used to determine leakage rate of IV middle main O-ring seal.

4.2.29 Begin timing for 3 minute dwell period.

4.2.30 Remove test port tool and associated equipment from backfill port.

4.2.31 Record He background (RT) after 3 minute dwell period on Attachment 7.

\section{SIGN-OFF}

4.2.32 Remove test assembly from MSLD.

4.2.33 Install calibrated leak to MSLD.

4.2.34 Perform post-test calibration of MSLD and record results on Attachment 7. 


\section{NOTE}

In Steps 4.2.35[ A ] through 4.2.35[ C ], only ONE condition can be true. The sign-off for this condition should be made on Attachment 7 . If the value of $(R B)$ is greater than (RT), then the value of (RT) will be substituted for the value of (RB) when performing leak rate calculations. If condition [C] applies, and this note is applicable to that condition (ending up with a negative number), then zero will be used as the leakage rate.

\subsubsection{Perform one of the following:}

[A ] If there is NO difference in the post-test calibration from the pretest calibration, use the following equation: Subtract the $\mathrm{He}$ background at the start of test (RB) from the $\mathrm{He}$ background at end of test (RT). The leakage rate is $(R T-R B) \times C C F$. This equals the leakage rate for this segment of the test.

\section{SIGN-OFF}

[ $B$ ] If post-test calibration is LESS than pretest calibration, use the following calculation: (RT + Calibration Difference - RB) $x$ CCF. This equals the leakage rate for this segment of the test under this condition of recalibration.

\section{SIGN-OFF}

[ C ] If post-test calibration is MORE than pretest calibration, use the following calculation: (RT - Calibration Difference - RB) $x$ CCF. If the result is negative, enter ZERO for the leakage rate. This equals the leakage rate for this segment of the test under this condition of recalibration.

\section{SIGN-OFF}

4.2.36 If acceptance criterion is satisfied $\left(\leq 2.6 \times 10^{-7} \mathrm{scc} / \mathrm{s} \mathrm{He}\right)$, this test segment is complete.

\section{NOTE}

Leakage rate acceptance criterion is $\leq 2.6 \times 10^{-7} \mathrm{scc} / \mathrm{s} \mathrm{He}$.

4.2.37 IF IV middle main O-ring seal leakage rate is $>2.6 \times 10^{-7} \mathrm{scc} / \mathrm{s} \mathrm{He}$, THEN perform the following:

[A ] Isolate leak path.

[ B ] GO TO WI-RH.02, replace O-ring seal(s) and/or WI-RH.07 to repair seal surface(s), and repeat leak test. 
[ C ] If after repeated testing it is clear that seal cannot pass test, prepare NCR and record on Attachment 7.

\section{SIGN-OFF}

4.2.38 Remove test port tool and associated leak test equipment from IV seal test port.

4.2.39 Install IV seal test port closure bolt.

4.2.40 Torque IV seal test port closure bolt to 15 to $20 \mathrm{lb}-\mathrm{ft}$.

\section{SIGN-OFF}

\subsection{Gas Sampling Port Closure Bolt O-ring Seal}

\section{NOTE}

The following test should be performed immediately after Subsection 4.2, IV Middle Main O-ring Seal, while He atmosphere is still present in IV backfill port cavity and to minimize He saturation of O-rings before test completion.

4.3.1 Remove residual He from gas sampling port by purging with nitrogen or argon.

4.3.2 Install a clean, He-free, test port tool into gas sampling port turning collar as needed to seat tool in test port.

\section{NOTE}

If Step 4.3.3 begins within 1 hour of completing IV middle main O-ring seal test, pretest calibration is NOT required. The post-test calibration result can be used for IV gas sampling port O-ring seal pretest calibration.

4.3.3 Perform pretest calibration of MSLD (to the temperature corrected standard leak value).

4.3.4 Record pretest calibration results on Attachment 7.

\section{SIGN-OFF}

4.3.5 Connect MSLD to test port tool installed in gas sampling port (see Figure 1.2, IV Gas Sampling Port Seal).

4.3.6 Evacuate IV test port tool. 


\section{NOTE}

To measure $\mathrm{a} \leq 2.6 \times 10^{-7} \mathrm{scc} / \mathrm{s}$ He leakage rate with He atmosphere already present, indicated He background must be $\leq 2.6 \times 10^{-7} \mathrm{scc} / \mathrm{s}$ He BEFORE the start of the dwell time.

Dwell time for IV gas sampling port O-ring seal test is 3 minutes. An initial indication does NOT necessarily indicate a leak. Residual He may still be detected.

4.3.7 Record He background (RT) after 3 minute dwell time on Attachment 7.

\section{SIGN-OFF}

4.3.8 Remove test assembly from MSLD.

4.3.9 Install calibrated leak to MSLD.

4.3.10 Perform post-test calibration of MSLD and record results on Attachment 7.

\section{SIGN-OFF}

\section{NOTE}

In Steps 4.3.11[ A ] through 4.3.11 [ C ], only ONE condition can be true. The sign-off for this condition should be made on Attachment 7 .

4.3.11 Calculate IV gas sampling port O-ring seal leakage rate as follows:

[A] If there is NO difference in the post-test calibration from the pretest calibration, the He background at end of test (RT x CCF) equals the leakage rate for this segment of the test.

\section{SIGN-OFF}

[ B ] If post-test calibration is LESS than pretest calibration, use the following calculation: (RT + Calibration Difference) x CCF.

This equals the leakage rate for this segment of the test under this condition of recalibration.

\section{SIGN-OFF}

[ $\mathrm{C}$ ] If post-test calibration is MORE than pretest calibration, use the following calculation: (RT - Calibration Difference) $x$ CCF. This equals the leakage rate for this segment of the test under this condition of recalibration. 
4.3.12 If acceptance criterion is satisfied $\left(\leq 2.6 \times 10^{-7} \mathrm{scc} / \mathrm{s} \mathrm{He}\right)$, this test segment is complete.

\section{NOTE}

Leakage rate acceptance criterion is $\leq 2.6 \times 10^{-7} \mathrm{scc} / \mathrm{s} \mathrm{He}$.

4.3.13 IF IV gas sampling port O-ring seal leakage rate is $>2.6 \times 10^{-7} \mathrm{scc} / \mathrm{s} \mathrm{He}$,

THEN perform the following:

[A] Isolate leak path.

[ B ] GO TO WI-RH.01, replace O-ring seal(s) and/or WI-RH.07 to repair seal surface(s), and repeat leak test.

[ C ] If after repeated testing it is clear that seal cannot pass test, prepare NCR and record on Attachment 7.

\section{SIGN-OFF}

4.3.14 Remove test port tools and associated equipment from gas sampling port.

\subsection{Backfill Port Closure Bolt O-ring Seal}

\section{NOTE}

The following test should be performed immediately after Subsection 4.3, IV Gas Sampling Port O-ring Seal, while He atmosphere is still present in IV backfill port cavity and to minimize $\mathrm{He}$ saturation of O-rings before test completion.

4.4.1 Using nitrogen, argon, or compressed air, remove residual He from backfill port.

4.4.2 Install a clean, He-free, test port tool into backfill port turning collar as needed to seat tool in test port.

\section{NOTE}

If Step 4.4 .3 begins within 1 hour of completing IV gas sampling port seal test, pretest calibration is NOT required. The post-test calibration result can be used for the IV backfill port O-ring seal pretest calibration.

4.4.3 Perform pretest calibration of MSLD (to the temperature corrected standard leak value).

4.4.4 Record pretest calibration results on Attachment 7. 
4.4.5 Connect MSLD to test port tool installed in backfill port (see Figure 1.3, IV Backfill Port Seal).

4.4.6 Evacuate IV test port tool.

\section{NOTE}

To measure $\mathrm{a} \leq 2.6 \times 10^{-7} \mathrm{scc} / \mathrm{s}$ He leakage rate with He atmosphere already present, indicated He background must be $\leq 2.6 \times 10^{-7} \mathrm{scc} / \mathrm{s} \mathrm{He} \mathrm{BEFORE}$ the start of the dwell time.

Dwell time for IV backfill port closure bolt O-ring seal test is 3 minutes. An initial indication does NOT necessarily indicate a leak. Residual He may still be detected.

4.4.7 Record helium background (RT) after 3 minute dwell period on Attachment 7.

\section{SIGN-OFF}

4.4.8 Remove test assembly from MSLD.

4.4.9 Install calibrated leak to MSLD.

4.4.10 Perform post-test calibration of MSLD and record results on Attachment 7.

\section{SIGN-OFF}

\section{NOTE}

In Steps 4.4.11[ A ] through 4.4.11[ C ], only ONE condition can be true. The sign-off for this condition should be made on Attachment 7 .

4.4.11 Calculate IV backfill port O-ring seal leakage rate as follows:

[A] If there is NO difference in the post-test calibration from the pretest calibration, the He background at end of test (RT x CCF) equals the leakage rate for this segment of the test.

\section{SIGN-OFF}

[B ] If post-test calibration is LESS than pretest calibration, use the following calculation: (RT + Calibration Difference) $x$ CCF. This equals the leakage rate for this segment of the test under this condition of recalibration.

\section{SIGN-OFF}


[C] If post-test calibration is MORE than pretest calibration, use the following calculation: (RT - Calibration Difference) $x$ CCF. This equals the leakage rate for this segment of the test under this condition of recalibration.

\section{SIGN-OFF}

4.4.12 If acceptance criterion is satisfied $\left(\leq 2.6 \times 10^{-7} \mathrm{scc} / \mathrm{s} \mathrm{He}\right)$, this test segment is complete.

\section{NOTE}

Leakage rate acceptance criterion is $\leq 2.6 \times 10^{-7} \mathrm{scc} / \mathrm{s} \mathrm{He}$.

4.4.13 IF IV backfill port O-ring seal leakage rate is $>2.6 \times 10^{-7} \mathrm{scc} / \mathrm{s} \mathrm{He}$, THEN perform the following:

[ A ] Isolate leak path.

[ B ] GO TO WI-RH.01, replace O-ring seal(s) and/or WI-RH.07 to repair seal surface(s), and repeat leak test.

[ C ] If after repeated testing it is clear that seal cannot pass test, prepare NCR and record on Attachment 1.

\section{SIGN-OFF}

4.4.14 Remove IV test port tool and associated equipment from backfill port.

4.5 OC Inner Main O-ring Seal

4.5.1 Record the following on Attachment 8, OC Pre-shipment Leakage Rate Test Data Sheet:

- OC body $S / N$

- OC lid $S / \mathrm{N}$

- Date of leak test

- MSLD model number

- Pressure/vacuum gauge $\mathrm{S} / \mathrm{N}$ and calibration due date

- Thermometer S/N and calibration due date

- Torque wrench $S / N$ s and calibration due dates

- Standard leak S/N and calibration due date

- Barometer S/N and calibration due date

\section{SIGN-OFF}

4.5.2 Verify OC lid is installed.

4.5.3 Verify OC seal test port closure bolt is installed. 
4.5.4 Verify OC gas sampling port closure bolt is installed.

4.5.5 Measure OC surface temperature and record on Attachment 8.

\section{SIGN-OFF}

4.5.6 If temperature is $<4.4^{\circ} \mathrm{C}$, stop test until surface temperature $\geq 4.4^{\circ} \mathrm{C}$.

4.5.7 Install a test port tool on the seal test port turning collar as needed to seat tool in test port.

4.5.8 Open the test port tool installed in the seal test port by turning the cap counterclockwise until bolt is completely retracted into tool.

4.5.9 Install a test port tool on gas sampling port turning collar as needed to seat tool in test port.

4.5.10 Open test port tool installed in gas sampling port by turning the cap counterclockwise until bolt is fully retracted into tool.

4.5.11 Connect vacuum pump assembly and He gas supply to test port tool on gas sampling port (see Figure 1.4, OC Containment Seal).

4.5.12 Open isolation valve to vacuum pump.

4.5.13 Record ambient atmospheric pressure (Patm) on Attachment 8.

\section{SIGN-OFF}

4.5.14 Start vacuum pump.

4.5.15 Evacuate OC cavity $\geq 90 \%$ vacuum $(90 \%$ of atmospheric pressure).

4.5.16 Record vacuum reading (V1) on Attachment 8.

\section{SIGN-OFF}

4.5.17 Calculate He concentration correction factor as follows:

$$
\mathrm{CCF}=\frac{\text { Patm }}{\mathrm{V} 1}
$$

\subsubsection{Record CCF on Attachment 8.}

\section{SIGN-OFF}

4.5.19 Perform pretest calibration of MSLD (to the temperature corrected standard leak value). 
4.5.20 Record pretest calibration results on Attachment 8.

\section{SIGN-OFF}

4.5.21 Attach MSLD to test port tool installed on seal test port (see Figure 1.4).

4.5.22 Evacuate seal test port using vacuum pump within MSLD.

4.5.23 Close vacuum valve and stop vacuum pump attached to gas sampling port.

\section{NOTE}

To measure $a \leq 2.6 \times 10^{-7} \mathrm{scc} / \mathrm{s}$ He leakage rate, indicated He background must stabilize at $\leq 2.6 \times 10^{-7} \mathrm{scc} / \mathrm{s} \mathrm{He}$ and remain below the limit for a minimum of 3 minutes.

4.5.24 Record He background (RB) on Attachment 8.

\section{SIGN-OFF}

4.5.25 Open He supply valve and backfill OC cavity with He to a pressure slightly greater than atmospheric pressure (+1 psi, $-0 \mathrm{psi})$.

4.5.26 Close He supply valve.

4.5.27 Record backfill pressure reading on Attachment 8 .

\section{SIGN-OFF}

4.5.28 Install gas sampling port closure bolt and torque to 15 to $20 \mathrm{lb}$-ft.

\section{SIGN-OFF}

\section{NOTE}

A dwell time of 3 minutes will be used to determine leakage rate of $\mathrm{OC}$ inner main O-ring seal.

4.5.29 Begin timing for 3 minute dwell period.

4.5.30 Remove test port tool and associated equipment from gas sampling port.

4.5.31 Record He background (RT) after 3 minute dwell period on Attachment 8.

\section{SIGN-OFF}

4.5.32 Disconnect MSLD from OC seal test port. 
4.5.33 Remove test port tool from OC seal test port.

4.5.34 Install OC seal test port closure bolt and torque to 15 to $20 \mathrm{lb}$-ft.

\section{SIGN-OFF}

4.5.35 Install calibrated leak to MSLD.

4.5.36 Perform post-test calibration of MSLD and record results on Attachment 8.

\section{SIGN-OFF}

\section{NOTE}

In Steps 4.5.37[ A ] through 4.5.37[ C ], only ONE condition can be true. The sign-off for this condition should be made on Attachment 8 . If the value of $(R B)$ is greater than (RT), then the value of (RT) will be substituted for the value of (RB) when performing leak rate calculations. If condition [C] applies, and this note is applicable to that condition (ending up with a negative number), then zero will be used as the leakage rate.

4.5.37 Calculate OC upper main O-ring seal leakage rate as follows:

[A ] If there is NO difference in the post-test calibration from the pretest calibration, use the following equation: Subtract the He background at the start of test (RB) from the He background at end of test (RT). The leakage rate is $(R T-R B) \times C C F$. This equals the leakage rate for this segment of the test.

\section{SIGN-OFF}

[B ] If post-test calibration is LESS than pretest calibration, use the following calculation: (RT + Calibration Difference - RB) $x$ CCF. This equals the leakage rate for this segment of the test under this condition of recalibration.

\section{SIGN-OFF}

[ C ] If post-test calibration is MORE than pretest calibration, use the following calculation: (RT - Calibration Difference - RB) $x$ CCF. If the result is negative, enter ZERO for the leakage rate. This equals the leakage rate for this segment of the test under this condition of recalibration.

\section{SIGN-OFF}

4.5.38 If acceptance criterion is satisfied $\left(\leq 2.6 \times 10^{-7} \mathrm{scc} / \mathrm{s} \mathrm{He}\right)$, this test segment is complete. 


\section{NOTE}

Leakage rate acceptance criterion is $\leq 2.6 \times 10^{-7} \mathrm{scc} / \mathrm{s} \mathrm{He}$.

4.5.39 IF OC main O-ring seal leakage rate is $>2.6 \times 10^{-7} \mathrm{scc} / \mathrm{s} \mathrm{He}$, THEN perform the following:

[ A ] Isolate leak path.

[ B ] GO TO WI-RH.02, replace O-ring seal(s) and/or WI-RH.07 to repair seal surface(s), and repeat leak test.

[ C ] If after repeated testing it is clear that seal cannot pass test, prepare NCR and record on Attachment 8.

\section{SIGN-OFF}

\section{NOTE}

The following test should be performed immediately after Subsection 4.5, while $\mathrm{He}$ atmosphere is still present in $\mathrm{OC}$ cavity and to minimize $\mathrm{He}$ saturation of O-rings before test completion.

4.6 OC Gas Sampling Port O-ring Seal

4.6.1 Verify the OC seal test port closure bolt is torqued to 15 to $20 \mathrm{lb}-\mathrm{ft}$.

SIGN-OFF

4.6.2 Purge gas sampling port using nitrogen, argon, or compressed air to flush out residual He.

4.6.3 Install clean, He-free, OC test port tool in OC gas sampling port turning collar as needed to seat tool in test port.

\section{NOTE}

If Step 4.6.4 begins within 1 hour of completing OC INNER main O-ring seal leak test, pretest calibration is NOT required. The post-test calibration result can be used for the OC gas sampling port O-ring seal pretest calibration.

4.6.4 Perform pretest calibration of MSLD (to the temperature corrected standard leak value).

4.6.5 Record pretest calibration results on Attachment 8.

\section{SIGN-OFF}

4.6.6 Connect MSLD to OC test port tool (see Figure 1.5, OC Gas Sampling Port Seal).

4.6.7 Evacuate OC test port tool. 


\section{NOTE}

To measure $\mathrm{a} \leq 2.6 \times 10^{-7} \mathrm{scc} / \mathrm{s}$ He leakage rate with He atmosphere already present, indicated He background must be $\leq 2.6 \times 10^{-7} \mathrm{scc} / \mathrm{s}$ He before the start of the dwell time.

Dwell time for OC gas sampling port O-ring seal test is 3 minutes. An initial indication does NOT necessarily indicate a leak. Residual He may still be detected.

4.6.8 Record He background (RT) after 3 minute dwell time on Attachment 8.

\section{SIGN-OFF}

4.6.9 Remove test assembly from MSLD.

4.6.10 Install calibrated leak to MSLD.

4.6.11 Perform post-test calibration of MSLD and record results on Attachment 8.

\section{SIGN-OFF}

\section{NOTE}

In Steps 4.6.12[ A ] through 4.6.12[ $\mathrm{C}$ ], only ONE condition can be true. The sign-off for this condition should be made on Attachment 8.

4.6.12 Calculate OC gas sampling port O-ring seal leakage rate as follows:

[A] If there is NO difference in the post-test calibration from the pretest calibration, the He background at end of test (RT) $x$ CCF equals the leakage rate for this segment of the test.

SIGN-OFF

[ B ] If post-test calibration is LESS than pretest calibration, use the following calculation: (RT + Calibration Difference) $x$ CCF. This equals the leakage rate for this segment of the test under this condition of recalibration.

\section{SIGN-OFF}

[ C ] If post-test calibration is MORE than pretest calibration, use the following calculation: (RT - Calibration Difference) $x$ CCF. This equals the leakage rate for this segment of the test under this condition of recalibration. 
4.6.13 If acceptance criterion is satisfied $\left(\leq 2.6 \times 10^{-7} \mathrm{scc} / \mathrm{s} \mathrm{He}\right)$, this test segment is complete.

\section{NOTE}

Leakage rate acceptance criterion is $\leq 2.6 \times 10^{-7} \mathrm{scc} / \mathrm{s} \mathrm{He}$.

4.6.14 IF OC gas sampling port O-ring seal leakage rate is $>2.6 \times 10^{-7} \mathrm{scc} / \mathrm{s} \mathrm{He}$, THEN perform the following:

[A] Isolate leak path.

[ B ] GO TO WI-RH.01, replace O-ring seal(s) and/or WI-RH.07 to repair seal surface(s), and repeat leak test.

[ C ] If after repeated testing it is clear that seal cannot pass test, prepare NCR and record on Attachment 8.

\section{SIGN-OFF}

4.6.15 Remove OC test port tool from OC gas sampling port. 
Figure 1.1. IV Containment Seal

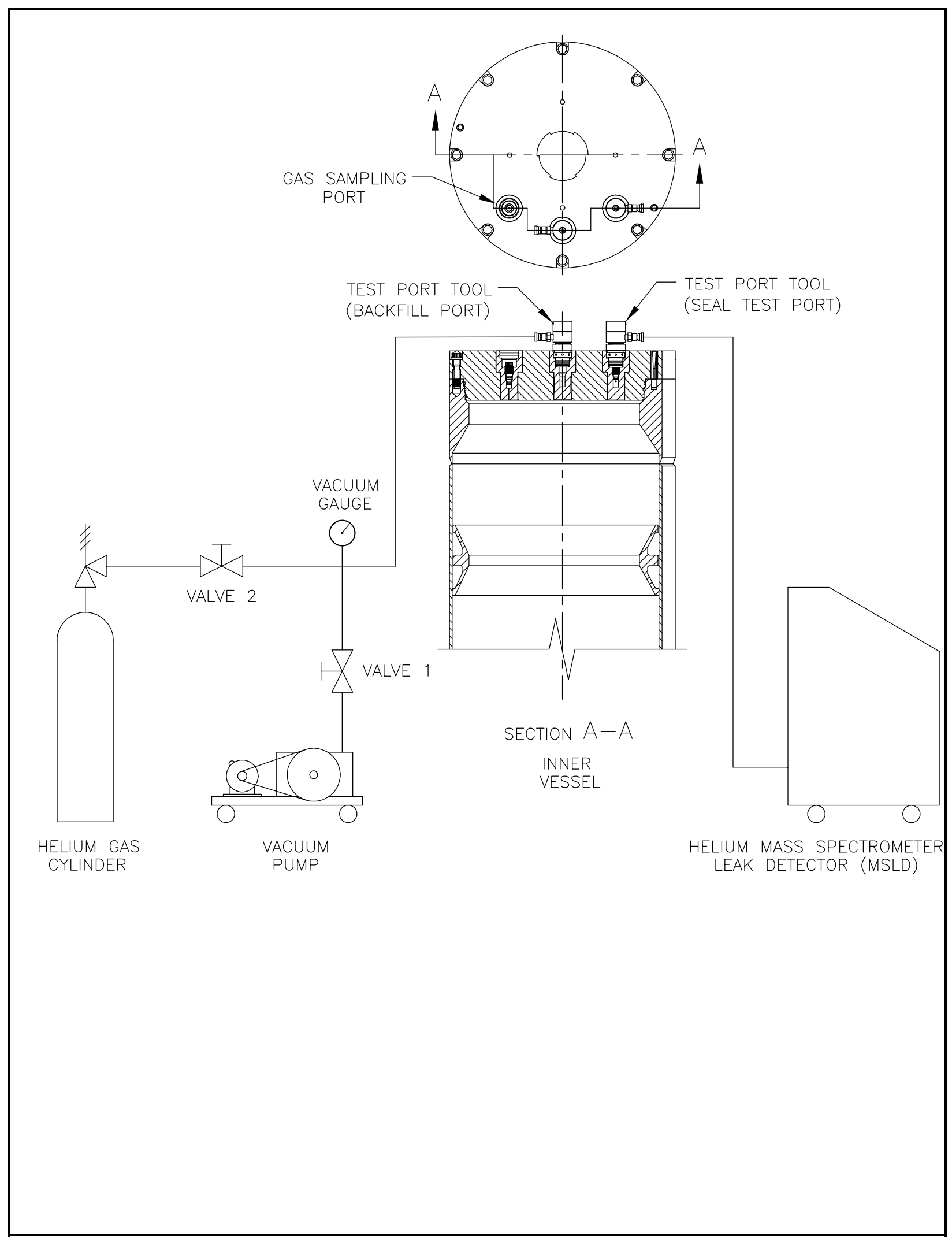


Figure 1.2. IV Gas Sampling Port Seal

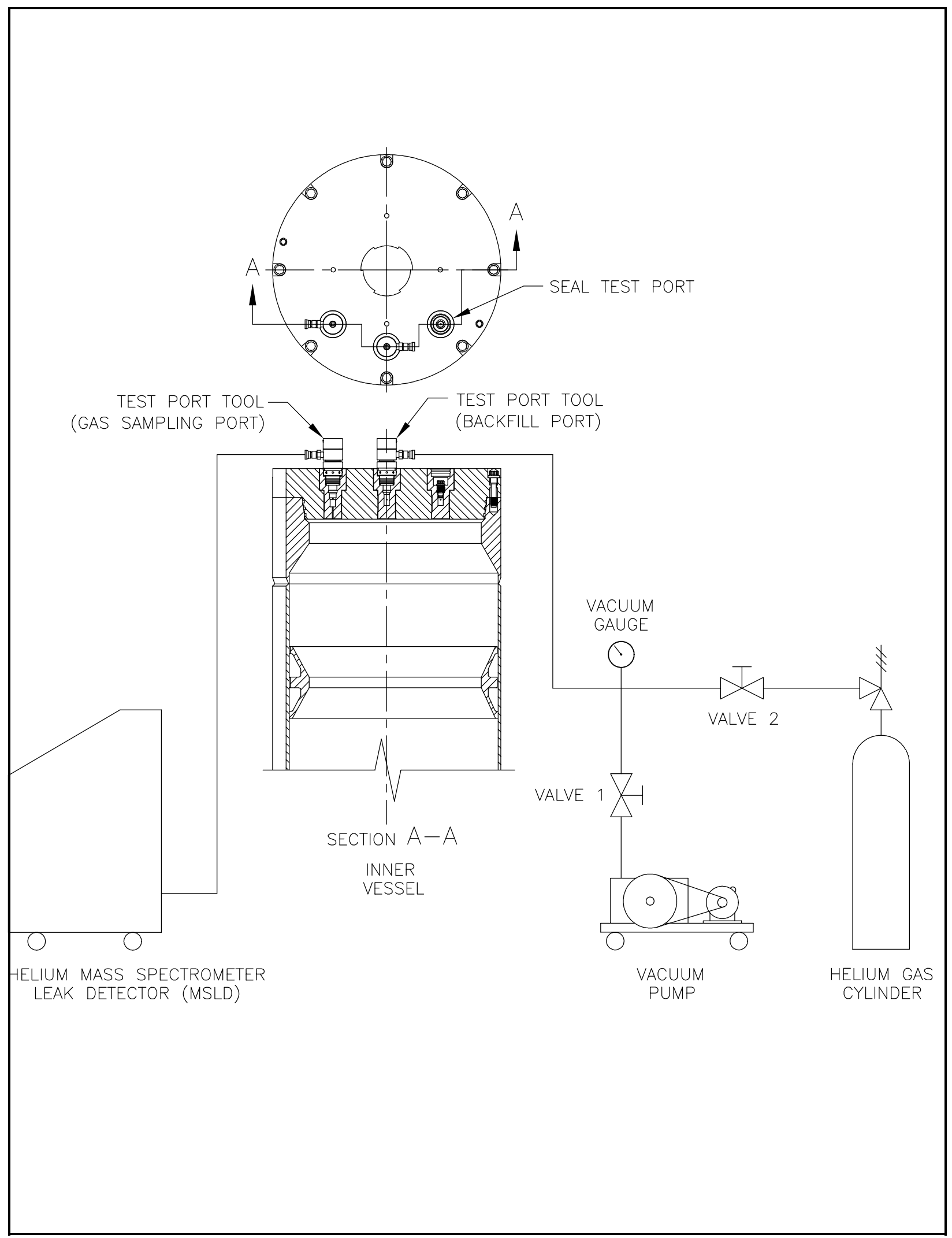


Rev. 0

Page 68 of 82

Figure 1.3. IV Backfill Port Seal

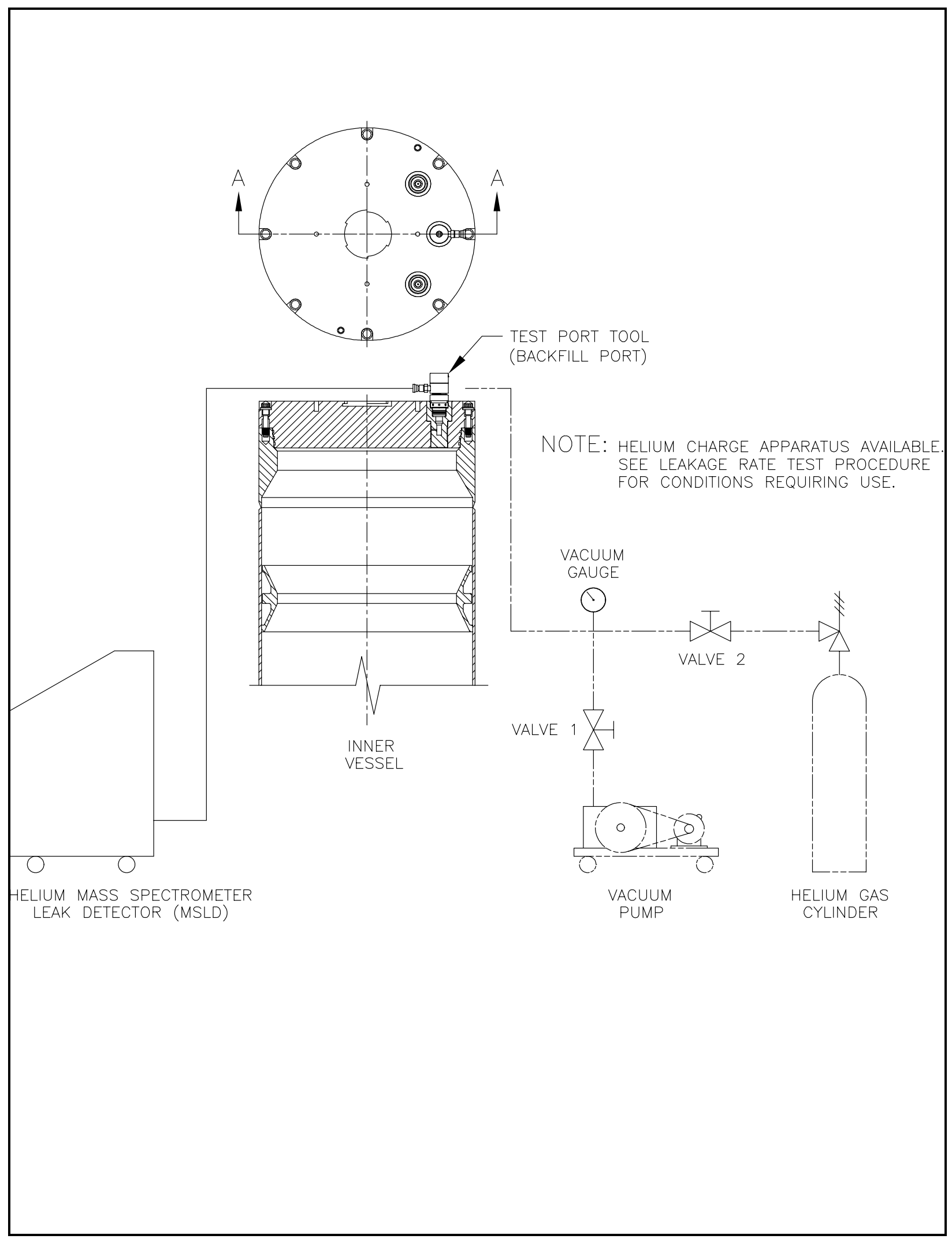


Rev. 0

Page 69 of 82

Figure 1.4. OC Containment Seal

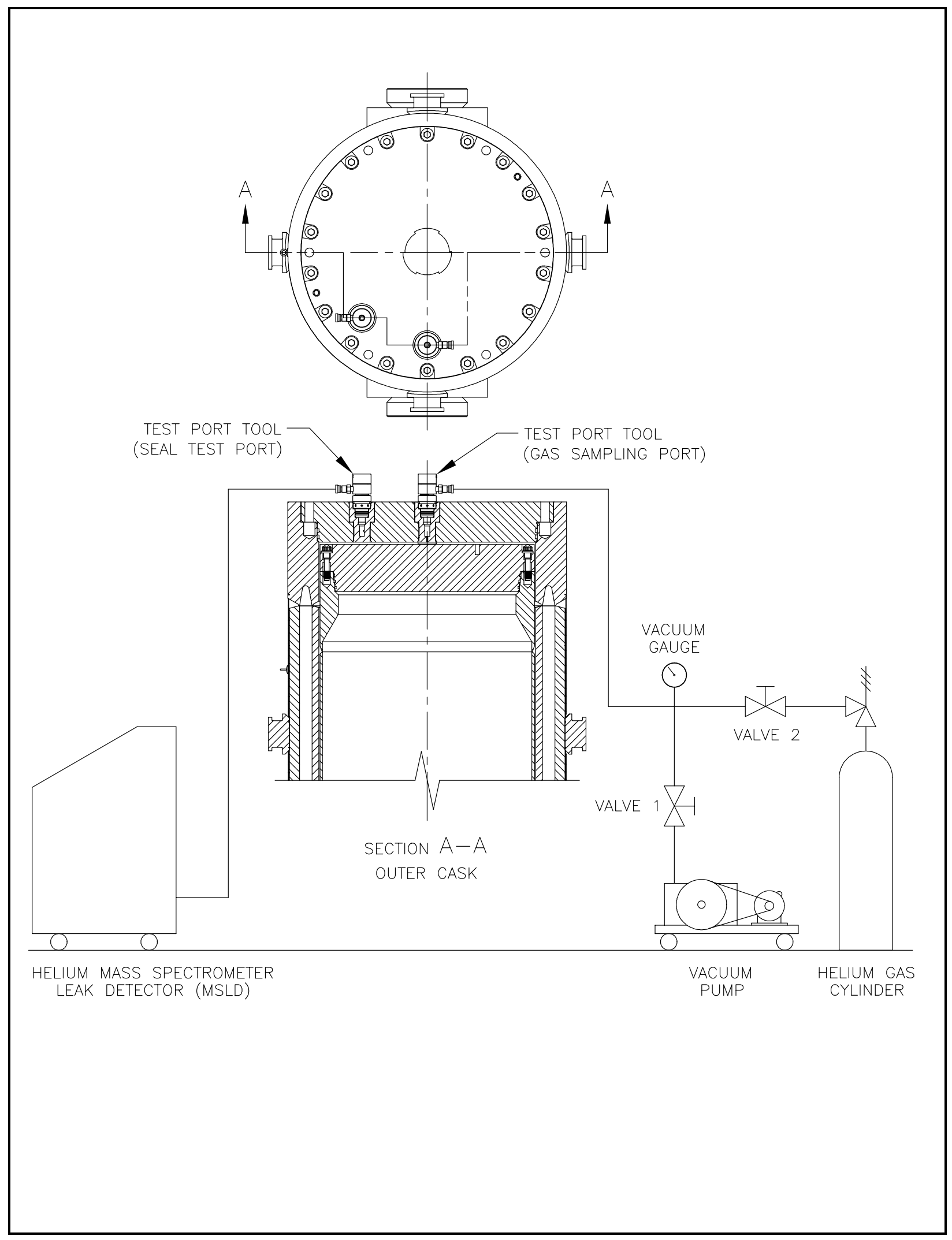


Figure 1.5. OC Gas Sampling Port Seal

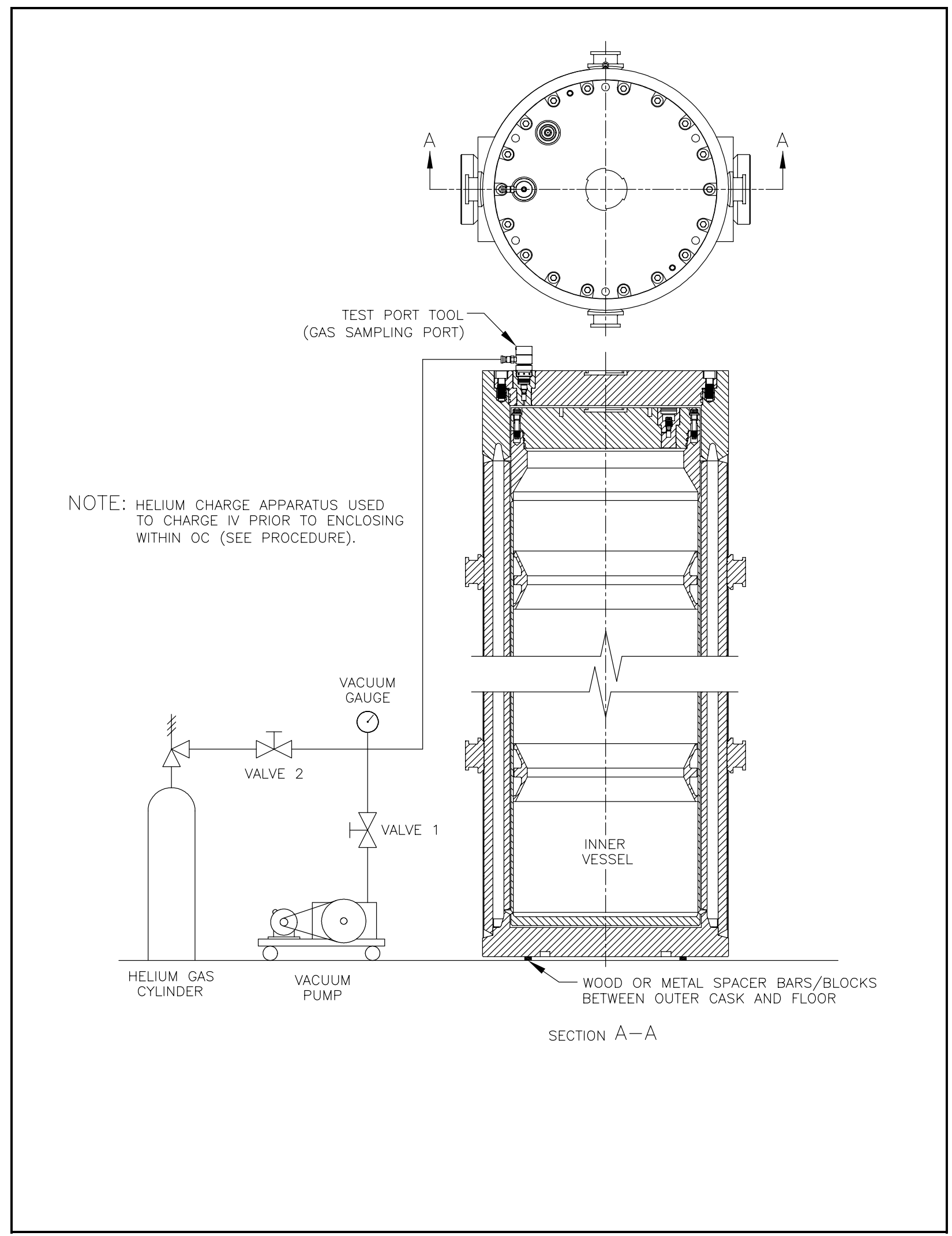




\section{Attachment 1 - Packaging Receipt and Inspection Data Sheet}

\begin{tabular}{|c|c|c|}
\hline \multicolumn{3}{|c|}{ Packaging Receipt and Inspection Data Sheet } \\
\hline STEP(S) & DESCRIPTION & INITIALS \\
\hline Facility: & Date: & \\
\hline 2.1 .1 & OC serial number: & \\
\hline \multicolumn{3}{|c|}{ PERFORMANCE } \\
\hline 2.1 .2 & $\begin{array}{l}\text { Shipping documents validated, packaging undamaged and released, and nameplate } \\
\text { checked }\end{array}$ & \\
\hline 2.1 .3 & Maintenance labels are present and maintenance is current & \\
\hline 2.7 .1 & $\begin{array}{l}\text { Activity on OC lid smears is within DOT acceptable limits } \\
\text { Survey No.: }\end{array}$ & \\
\hline 2.7 .13 & OC lid components and hardware satisfactory & \\
\hline 2.8.1 & $\begin{array}{l}\text { Activity on IV lid smears is within DOT acceptable limits } \\
\text { Survey No.: }\end{array}$ & \\
\hline 2.8 .13 & IV lid components and hardware satisfactory & \\
\hline 2.9 .1 & $\begin{array}{l}\text { Activity on IV interior and OC exterior smears is within DOT acceptable limits } \\
\text { Survey No.: } \\
\text { Survey Date: }\end{array}$ & \\
\hline 2.9 .4 & IV and OC body components and hardware are satisfactory & \\
\hline 2.10 .4 & IV cavity inspection complete & \\
\hline 2.11 .1 & $\begin{array}{l}\text { Activity on impact limiter contamination smears is within DOT acceptable limits } \\
\text { Survey No.: }\end{array}$ & \\
\hline 2.11 .4 & Impact limiters and hardware satisfactory & \\
\hline \multicolumn{3}{|l|}{2.11 .5} \\
\hline REVIEW/V & Supervisor (Print Name) & Date \\
\hline
\end{tabular}

Performers, enter printed name, signature, date and initials:

\section{Printed Name}

REMARKS:

\section{Signature}

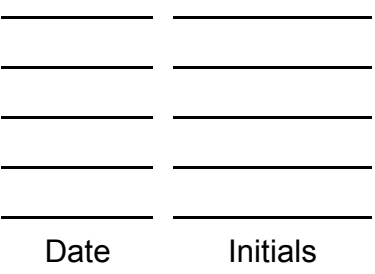

\section{REMARKS:}




\section{Attachment 2 - Packaging Loading Data Sheet}

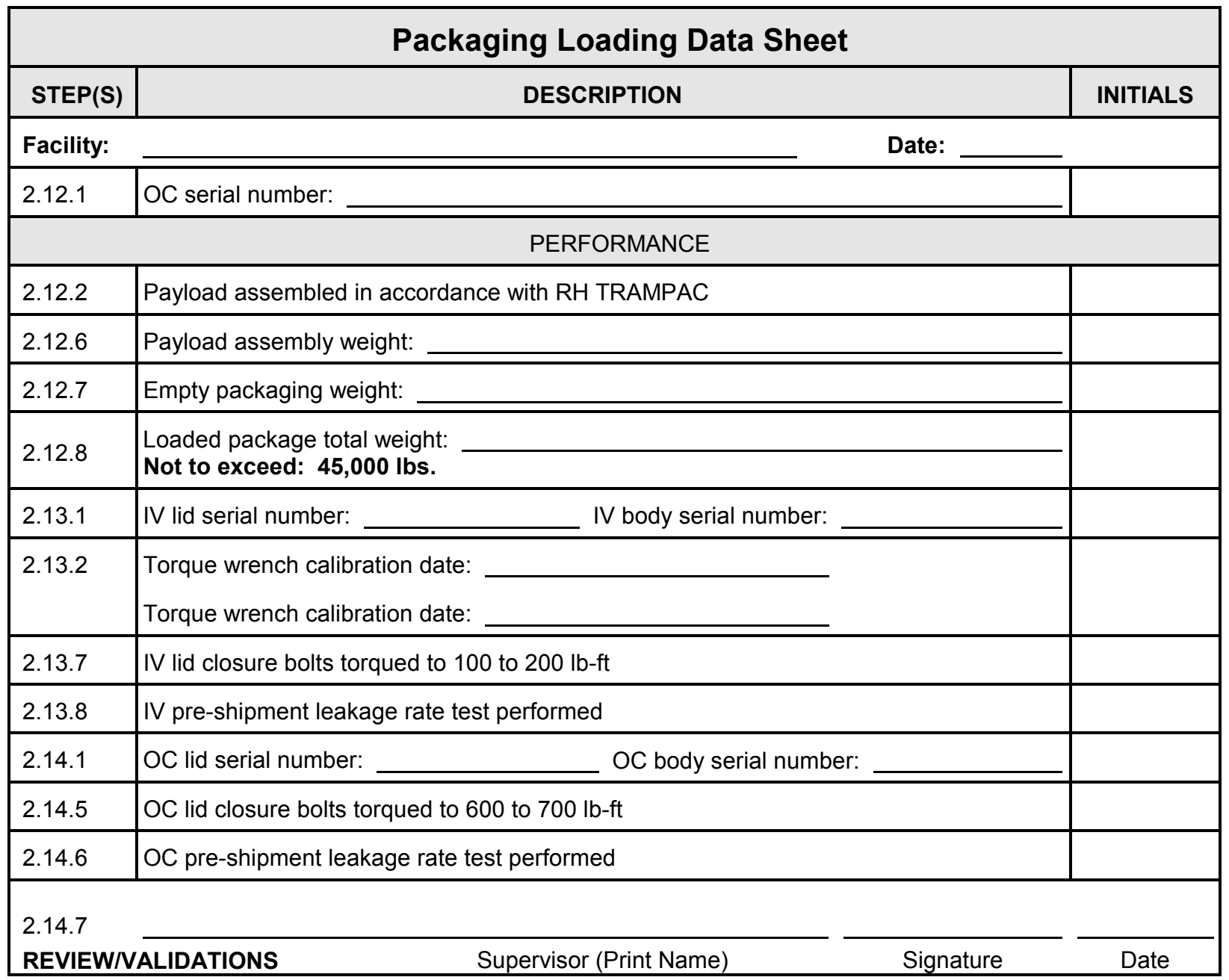

Performers, enter printed name, signature, date and initials:

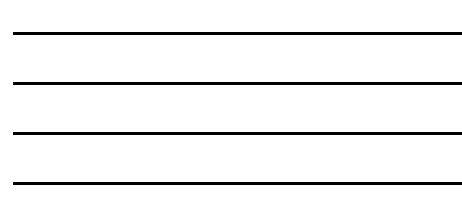

Printed Name
Signature

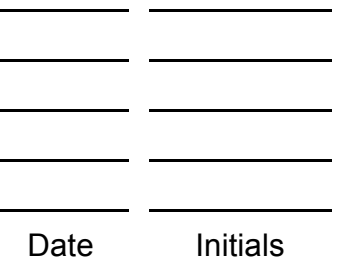

REMARKS: 


\section{Attachment 3 - Package Trailer Data Sheet}

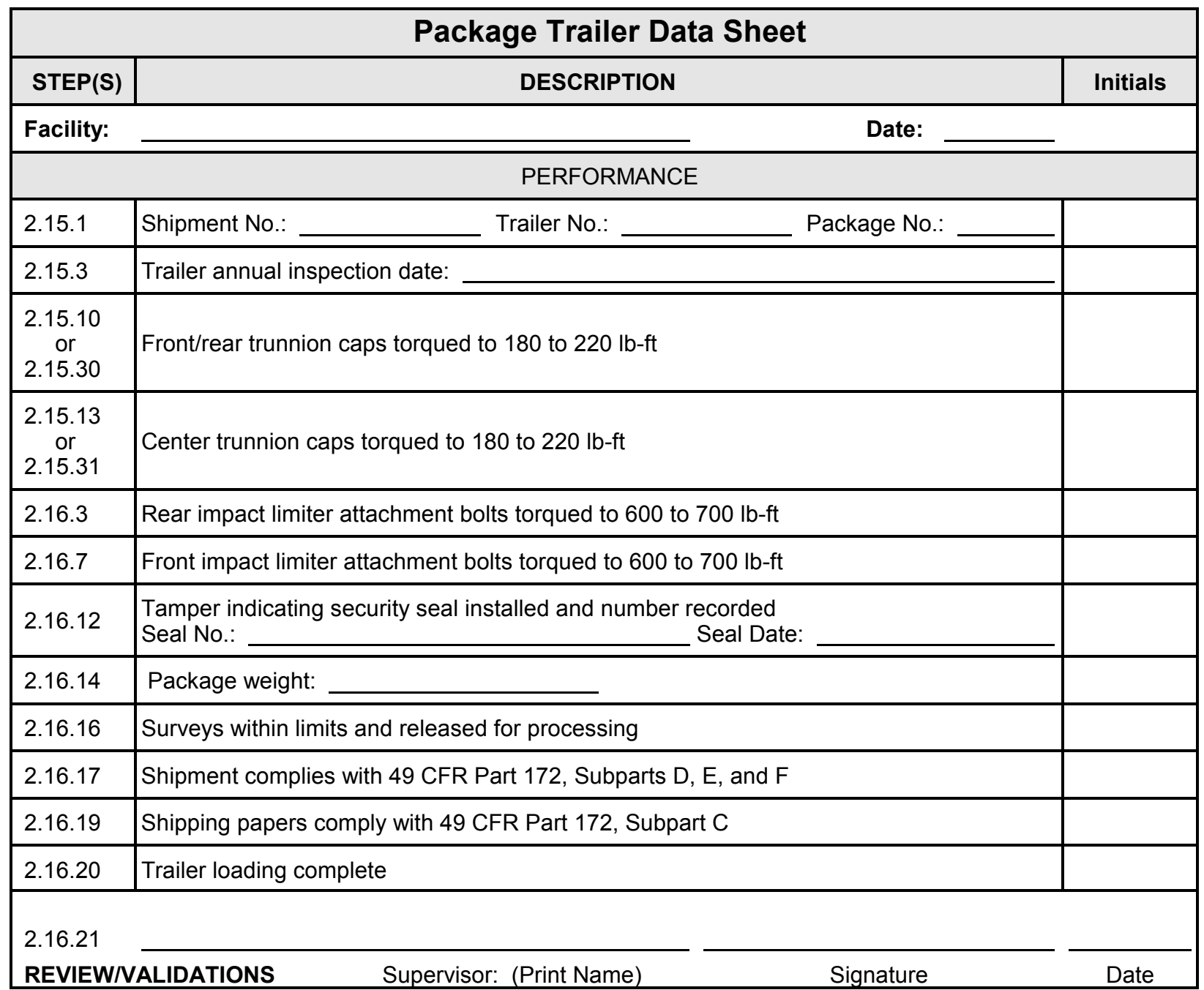

Performers, enter printed name, signature, date and initials:

Printed Name

REMARKS:
Signature

\section{Initials}




\section{Attachment 4 - Package Receipt and Processing Data Sheet}

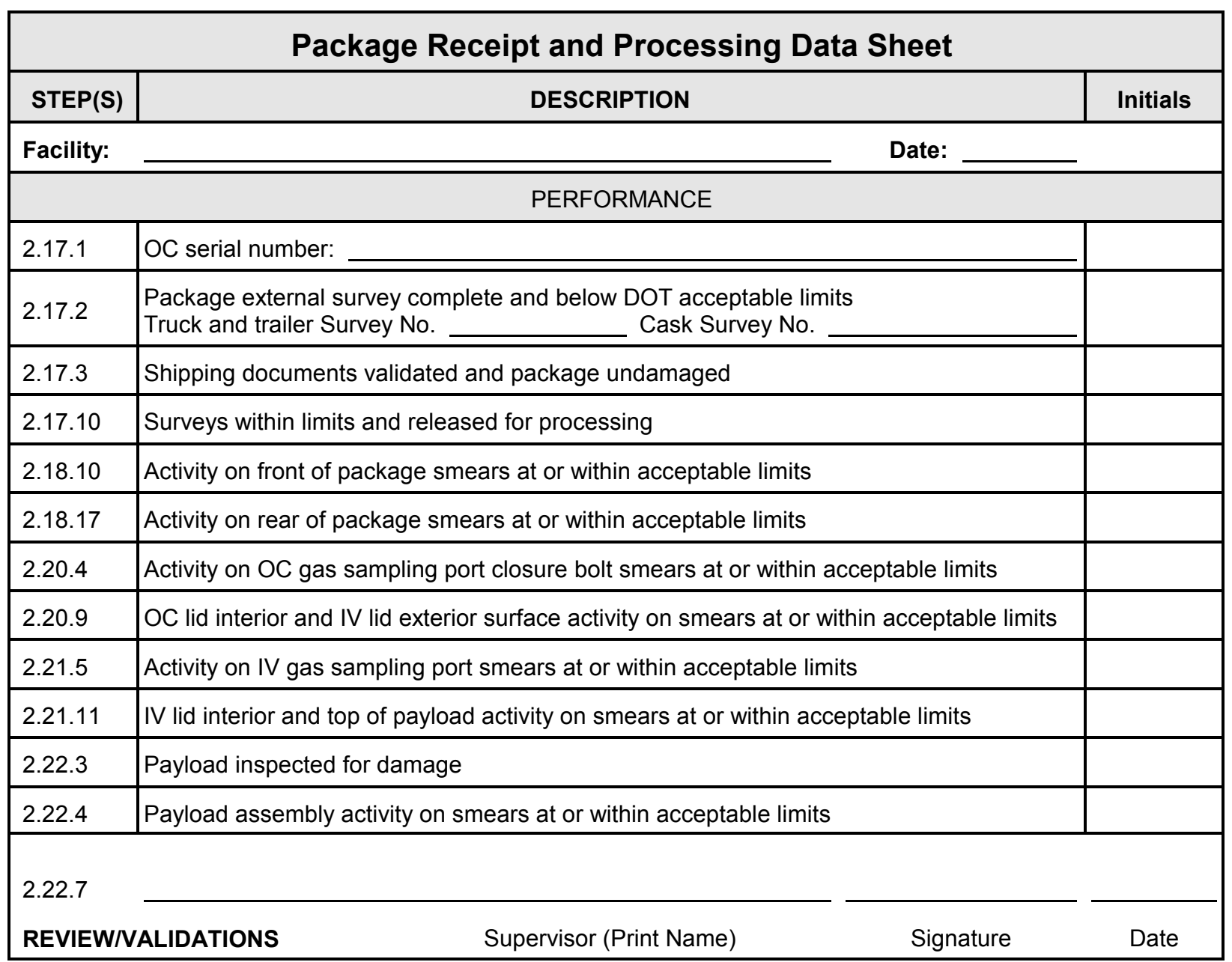

Performers, enter printed name, signature, date and initials:

REMARKS: 


\section{Attachment 5 - Packaging Shipment Data Sheet}

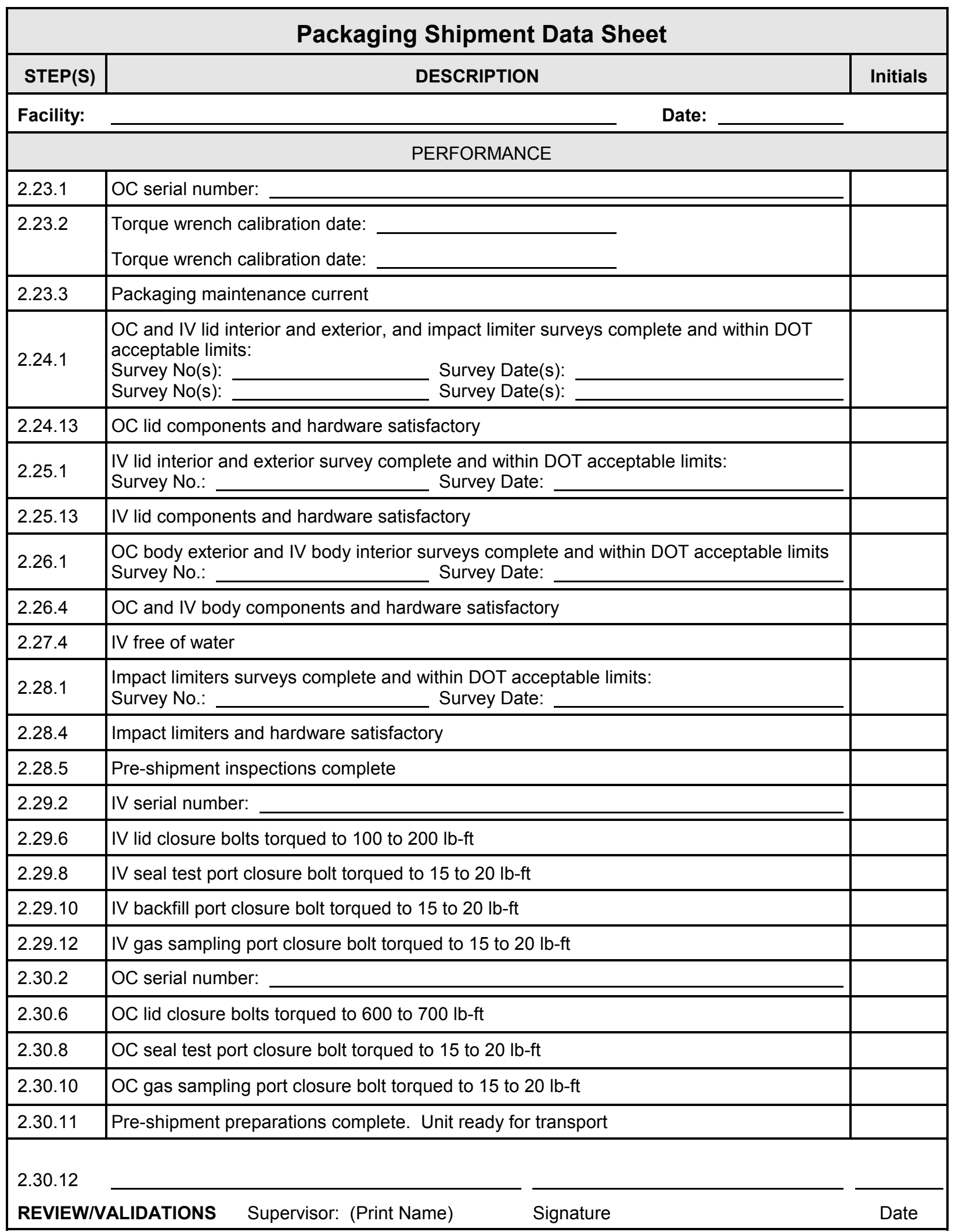




\section{Attachment 5 - Packaging Shipment Data Sheet}

Performers, enter printed name, signature, date and initials:

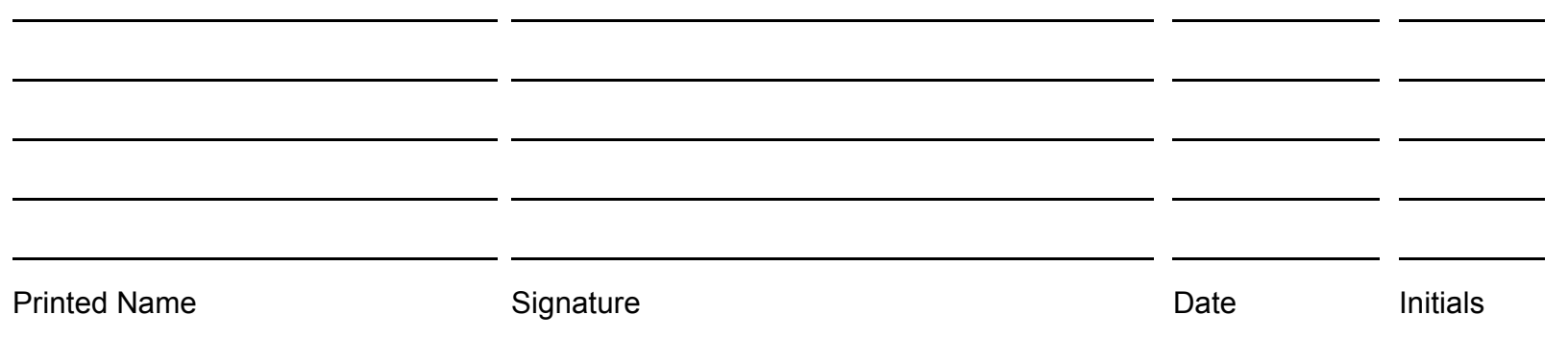

REMARKS: 


\section{Attachment 6 - Trailer Data Sheet}

\begin{tabular}{|c|c|c|}
\hline \multicolumn{3}{|c|}{ Trailer Data Sheet } \\
\hline STEP(S) & DESCRIPTION & Initials \\
\hline \multicolumn{2}{|l|}{ Facility: } & \\
\hline \multicolumn{3}{|c|}{ PERFORMANCE } \\
\hline 2.31 .1 & Shipment No.: _ _ Trailer No.: __ Package No.: & \\
\hline 2.31 .3 & Trailer inspection date: & \\
\hline $\begin{array}{c}2.31 .11 \\
\text { or } \\
2.31 .30\end{array}$ & Front/rear trunnion caps torqued to 180 to $220 \mathrm{lb}-\mathrm{ft}$ & \\
\hline $\begin{array}{c}2.31 .14 \\
\text { or } \\
2.31 .31\end{array}$ & Center trunnion caps torqued to 180 to $220 \mathrm{lb}-\mathrm{ft}$ & \\
\hline 2.32 .3 & Rear impact limiter attachment bolts torqued to 600 to $700 \mathrm{lb}-\mathrm{ft}$ & \\
\hline 2.32 .7 & Front impact limiter attachment bolts torqued to 600 to $700 \mathrm{lb}-\mathrm{ft}$ & \\
\hline 2.32 .12 & Packaging weight: & \\
\hline 2.32 .13 & Shipment complies with 49 CFR Part 172, Subparts D, E, and F & \\
\hline 2.32 .15 & Shipping papers comply with 49 CFR Part 172, Subpart C & \\
\hline 2.32 .16 & Trailer loading complete & \\
\hline \multicolumn{3}{|l|}{2.32 .17} \\
\hline REVIEW/V & ALIDATIONS Supervisor: (Print Name) & Date \\
\hline
\end{tabular}

Performers, enter printed name, signature, date and initials:

\section{Printed Name}

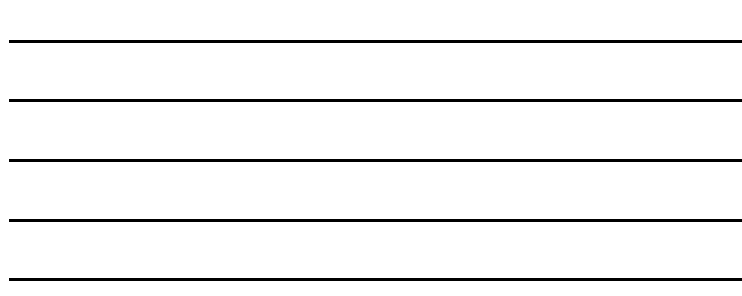

Signature

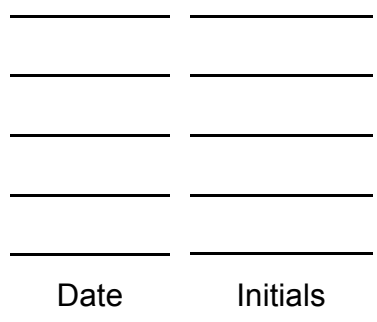

REMARKS: 


\section{Attachment 7 - IV Pre-shipment Leakage Rate Test Data Sheet}

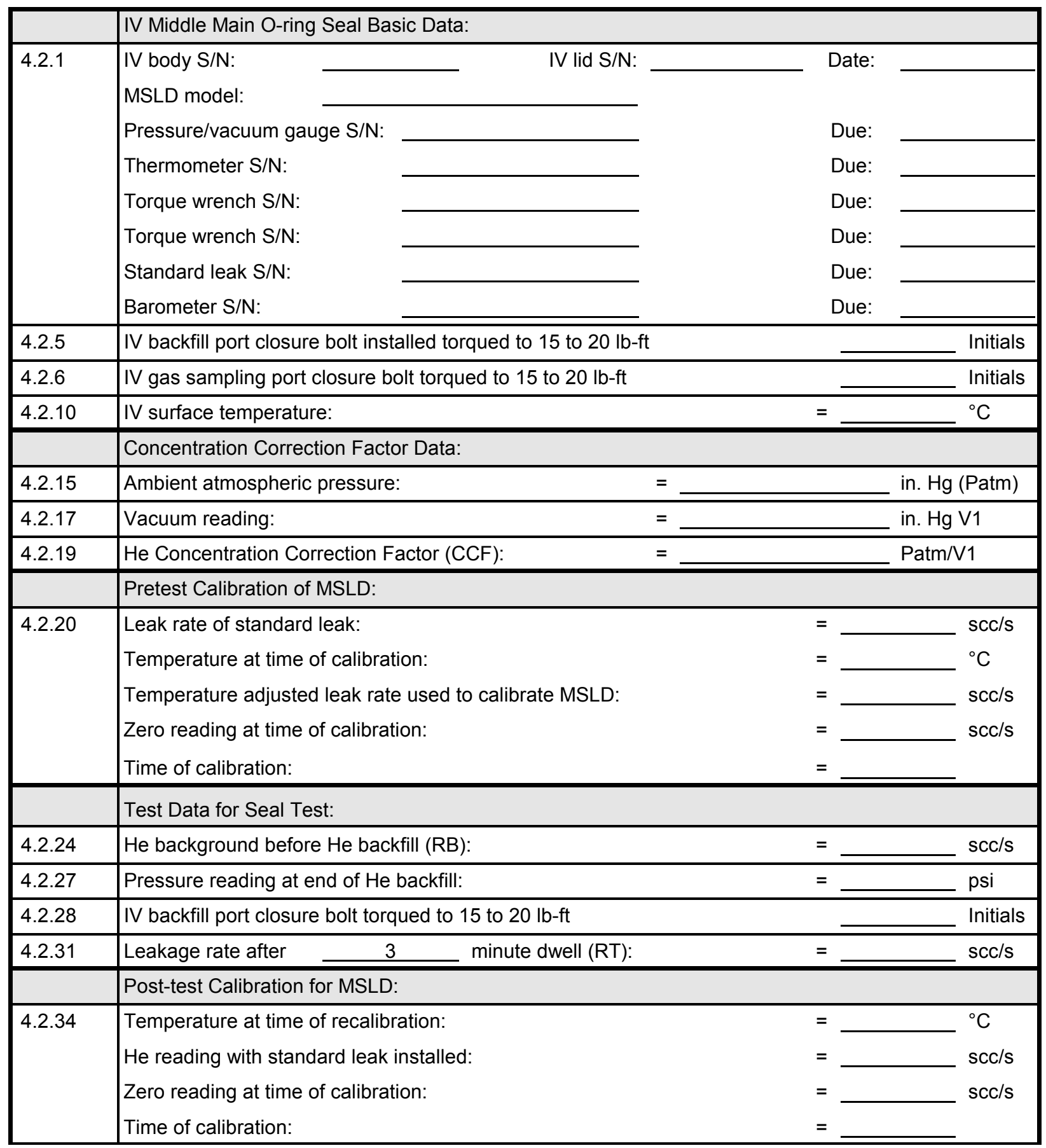




\section{Attachment 7 - IV Pre-shipment Leakage Rate Test Data Sheet}

\begin{tabular}{|c|c|c|}
\hline & ate Calculation: & \\
\hline $4.2 .35[\mathrm{~A}]$ & $\begin{array}{l}\text { If there is NO difference in the post-test calibration from the pretest calibration, use the following } \\
\text { equation: } \\
\text { Leak Rate = ( RT - RB ) X CCF } \\
\text { LR = ( }\end{array}$ & $\mathrm{scc} / \mathrm{s}$ \\
\hline $4.2 .35[B]$ & $\begin{array}{l}\text { If the post-test calibration is LESS than the pretest calibration, add the calibration difference: } \\
\text { Leak Rate }=(\mathrm{RT}+\text { Calibration Difference - RB }) \times \text { CCF } \\
\text { LR }=(\end{array}$ & $\mathrm{scc} / \mathrm{s}$ \\
\hline $4.2 .35[\mathrm{C}]$ & $\begin{array}{l}\text { If the post-test calibration is MORE than the pretest calibration, subtract the calibration differenc } \\
\text { Leak Rate }=(\text { RT - Calibration Difference - RB ) X CCF } \\
\text { LR }=(\end{array}$ & ce: \\
\hline $4.2 .37[\mathrm{C}]$ & NCR number recorded: & Initials \\
\hline \multirow[t]{2}{*}{4.2 .40} & IV seal test port closure bolt torqued to 15 to $20 \mathrm{lb}-\mathrm{ft}$ & Initials \\
\hline & Pretest Calibration for IV Gas Sampling Port Plug O-ring Seal: & \\
\hline 4.3 .4 & $\begin{array}{l}\text { Leak rate of standard leak: } \\
\text { Temperature at time of calibration: } \\
\text { Temperature adjusted leak rate used to calibrate MSLD: } \\
\text { Zero reading at time of calibration: } \\
\text { Time of calibration: }\end{array}$ & $\begin{array}{l}\mathrm{scc} / \mathrm{s} \\
{ }^{\circ} \mathrm{C} \\
\mathrm{scc} / \mathrm{s} \\
\mathrm{scc} / \mathrm{s}\end{array}$ \\
\hline \multirow[t]{2}{*}{4.3 .7} & He background after $\quad 3$ & $\mathrm{scc} / \mathrm{s}$ \\
\hline & Post-test Calibration for IV Gas Sampling Port Plug O-ring Seal: & \\
\hline \multirow[t]{2}{*}{ 4.3.10 } & $\begin{array}{l}\text { Temperature at time of recalibration: } \\
\text { He reading with standard leak installed: } \\
\text { Zero reading at time of calibration: } \\
\text { Time of calibration: }\end{array}$ & $\begin{array}{l}{ }^{\circ} \mathrm{C} \\
\mathrm{scc} / \mathrm{s} \\
\mathrm{scc} / \mathrm{s}\end{array}$ \\
\hline & Leak Rate Calculation: & \\
\hline 4.3.11[A ] & $\begin{array}{l}\text { If there is NO difference in the post-test calibration from the pretest calibration, use the following } \\
\text { equation: } \\
\text { Leak Rate = RT X CCF } \\
\mathrm{LR}=\end{array}$ & \\
\hline $4.3 .11[B]$ & $\begin{array}{l}\text { If the post-test calibration is LESS than the pretest calibration, add the calibration difference: } \\
\left.\qquad \begin{array}{l}\text { Leak Rate }=(\mathrm{RT}+\text { Calibration Difference }) \times C C F \\
\mathrm{LR}=(\end{array}\right) \times C \mathrm{CCF}\end{array}$ & $\mathrm{scc} / \mathrm{s}$ \\
\hline 4.3.11[ C ] & $\begin{array}{l}\text { If the post-test calibration is MORE than the pretest calibration, subtract the calibration differen } \\
\text { Leak Rate = ( RT - Calibration Difference }) \times C C F \\
L R=(\end{array}$ & scc/s \\
\hline $4.3 .13[\mathrm{C}]$ & NCR number recorded: & Initials \\
\hline
\end{tabular}




\section{Attachment 7 - IV Pre-shipment Leakage Rate Test Data Sheet}

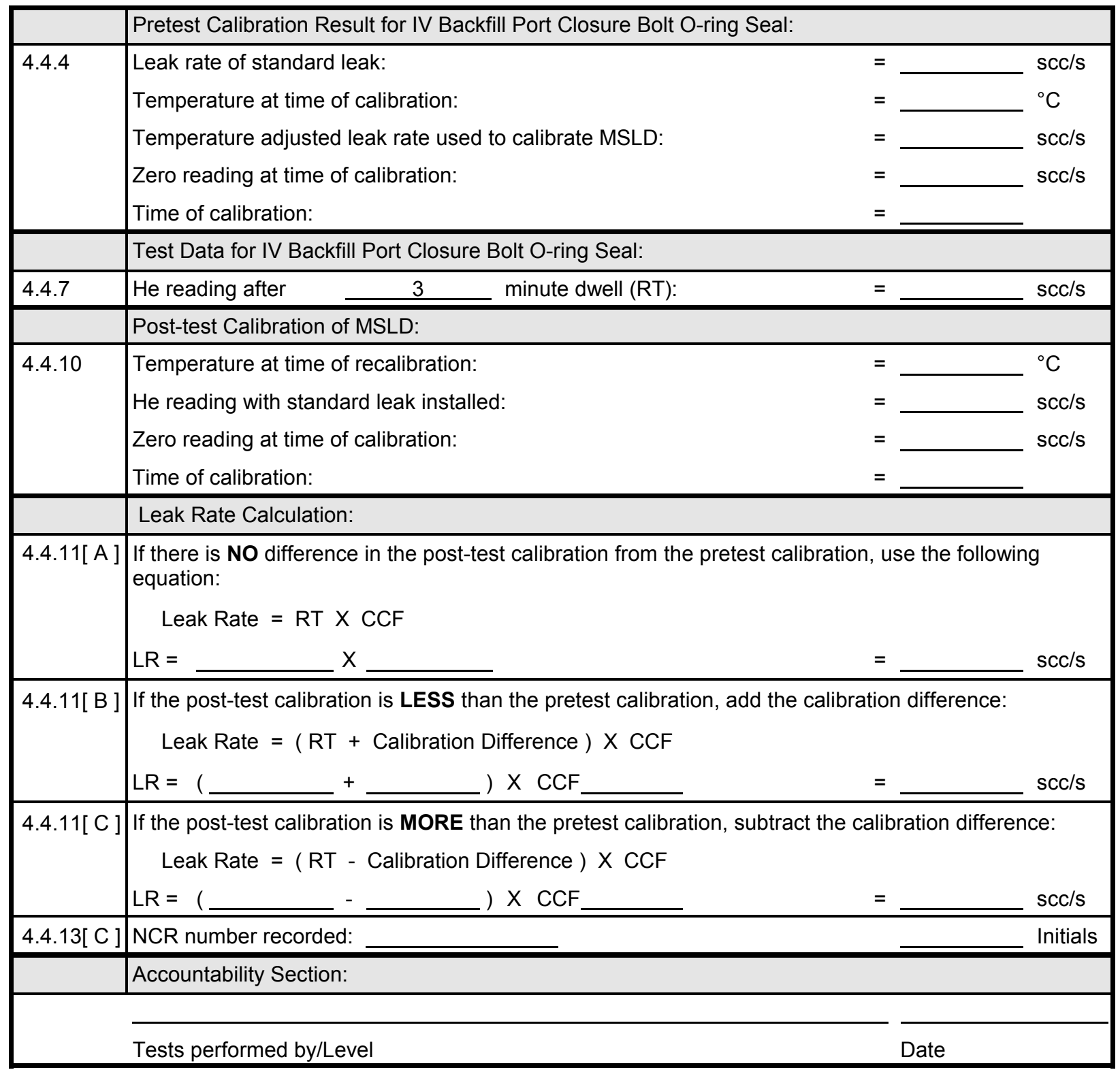




\section{Attachment 8 - OC Pre-shipment Leakage Rate Test Data Sheet}

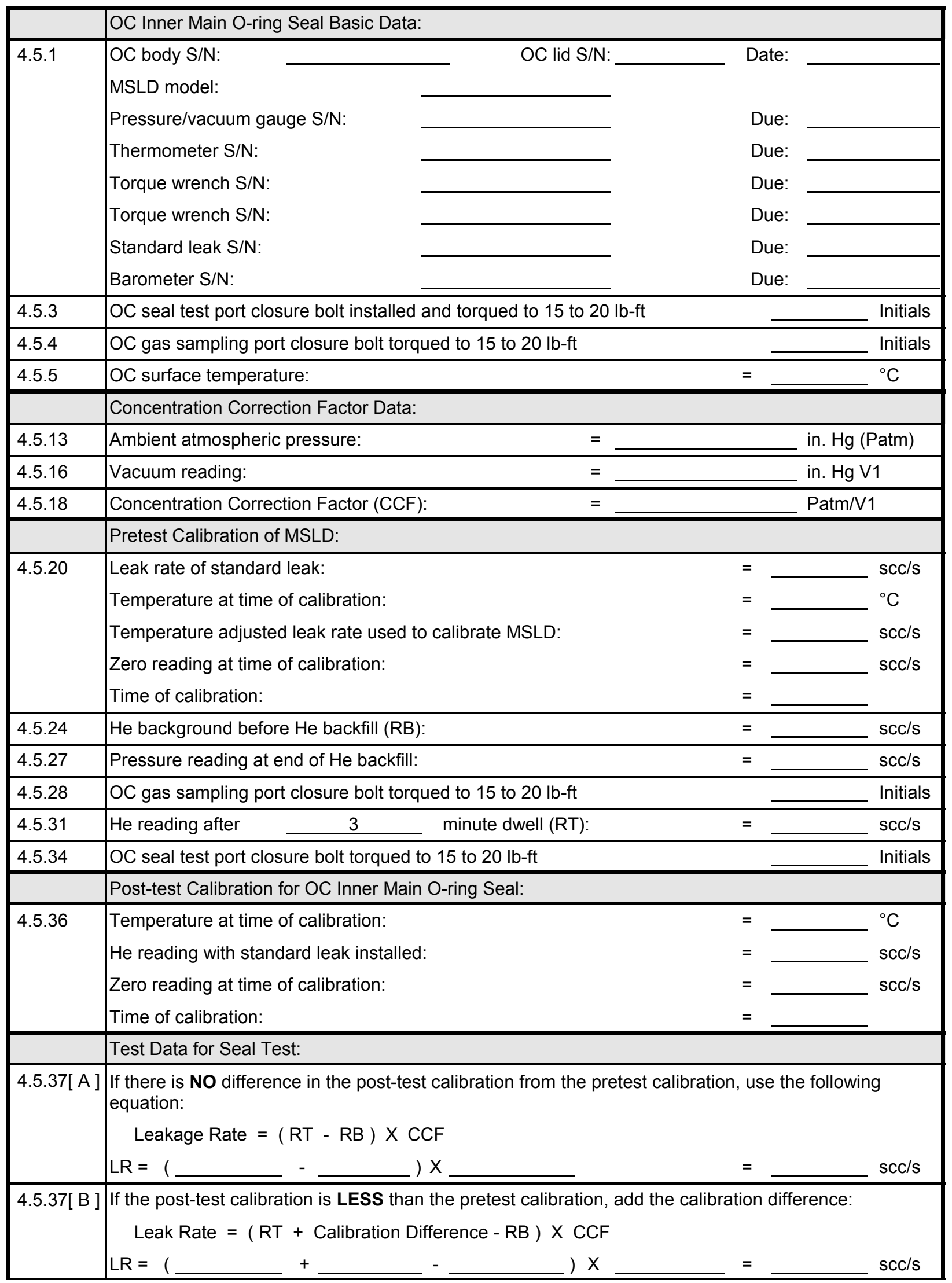




\section{Attachment 8 - OC Pre-shipment Leakage Rate Test Data Sheet}

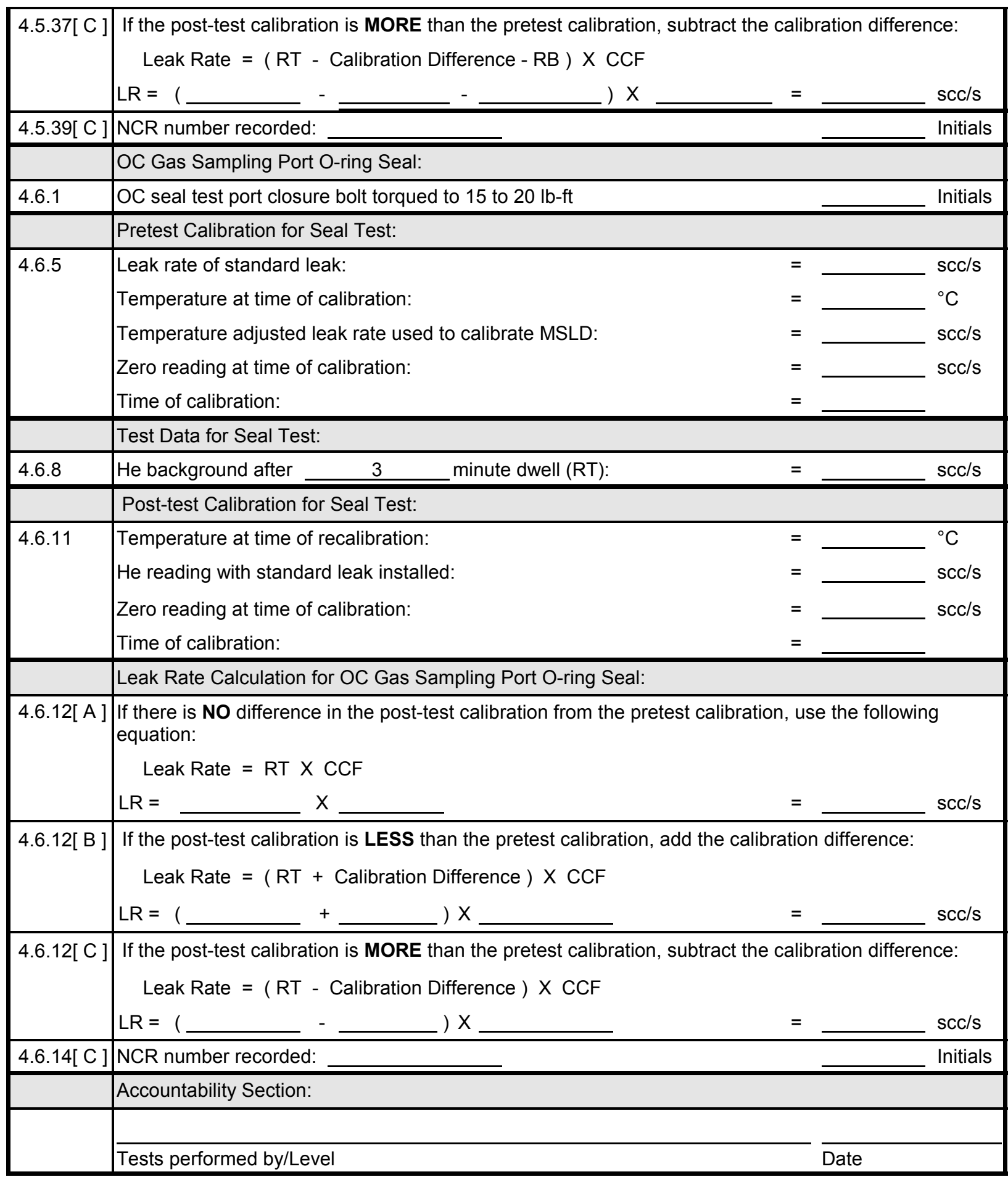

